\title{
N-phenyl-6-chloro-4-hydroxy-2-quinolone-3-carboxamides: Molecular Docking, Synthesis, and Biological Investigation as Anticancer Agents
}

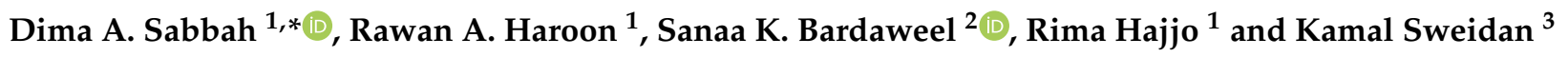 \\ 1 Department of Pharmacy, Faculty of Pharmacy, Al-Zaytoonah University of Jordan, Amman 11733, Jordan; \\ rawan21993.ra@gmail.com (R.A.H.); r.hajjo@zuj.edu.jo (R.H.) \\ 2 Department of Pharmaceutical Sciences, School of Pharmacy, The University of Jordan, Amman 11942, Jordan; \\ s.bardaweel@ju.edu.jo \\ 3 Department of Chemistry, The University of Jordan, Amman 11942, Jordan; k.sweidan@ju.edu.jo \\ * Correspondence: dima.sabbah@zuj.edu.jo; Tel.: +962-64291511
}

check for updates

Citation: Sabbah, D.A.; Haroon, R.A.; Bardaweel, S.K.; Hajjo, R.; Sweidan, K

$N$-phenyl-6-chloro-4-hydroxy-2quinolone-3-carboxamides: Molecular Docking, Synthesis, and Biological Investigation as Anticancer Agents. Molecules 2021, 26, 73. https:// doi.org/10.3390/molecules 26010073

Academic Editor: Isabelle Mus-Veteau Received: 30 November 2020 Accepted: 23 December 2020 Published: 25 December 2020

Publisher's Note: MDPI stays neutral with regard to jurisdictional clai$\mathrm{ms}$ in published maps and institutional affiliations.

Copyright: (C) 2020 by the authors. Licensee MDPI, Basel, Switzerland. This article is an open access article distributed under the terms and conditions of the Creative Commons Attribution (CC BY) license (https:// creativecommons.org/licenses/by/ $4.0 /)$.

\begin{abstract}
Cancer is a multifactorial disease and the second leading cause of death worldwide. Diverse factors induce carcinogenesis, such as diet, smoking, radiation, and genetic defects. The phosphatidylinositol 3-kinase (PI3K $\alpha$ ) has emerged as an attractive target for anticancer drug design. Eighteen derivatives of $\mathrm{N}$-phenyl-6-chloro-4-hydroxy-2-quinolone-3-carboxamide were synthesized and characterized using FT-IR, NMR $\left({ }^{1} \mathrm{H}\right.$ and $\left.{ }^{13} \mathrm{C}\right)$, and high-resolution mass spectra (HRMS). The series exhibited distinct antiproliferative activity $\left(\mathrm{IC}_{50} \mu \mathrm{M}\right)$ against human epithelial colorectal adenocarcinoma (Caco-2) and colon carcinoma (HCT-116) cell lines, respectively: compounds 16 (37.4, 8.9 $\mu \mathrm{M}), \mathbf{1 8}(50.9,3.3 \mu \mathrm{M}), \mathbf{1 9}(17.0,5.3 \mu \mathrm{M})$, and $21(18.9,4.9 \mu \mathrm{M})$. The induced-fit docking (IFD) studies against PI3K $\alpha$ s showed that the derivatives occupy the PI3K $\alpha$ binding site and engage with key binding residues.
\end{abstract}

Keywords: anticancer; colon cancer; PI3K $\alpha$; AKT; docking; quinolone-3-carboxamide

\section{Introduction}

The emergence of cancer cases continues to rise worldwide. Cancer, a group of diseases, is considered a prevalent health problem and cause of death. Cancer is uncontrolled cell proliferation accompanied with invasion to other body organs [1]. Multiple factors induce cancer occurrence, such as smoking, diet, radiation, viral infections, and genetic disorders [2-5]. Phosphatidylinositol 3-kinases (PI3Ks) catalyze the phosphorylation of phosphatidylinositol on the 3-OH group of inositol ring generating phosphatidylinositol 3,4,5 triphosphates $\left(\mathrm{PIP}_{3}\right)$. PIP 3 invoke downstream effectors and signaling proteins such as protein kinase $\mathrm{B}(\mathrm{AKT})$ inducing cell growth and multiplication $[6,7]$.

The phosphatase and tensin homolog (PTEN) dephosphorylates the 3-OH group of $\mathrm{PIP}_{3}$ producing $\mathrm{PIP}_{2}$ and therefore antagonizes PI3Ks [7,8]. PI3Ks are organized into three classes (I, II, and III) according to their substrate interaction and protein sequence. Class IA PI3Ks accommodate PI3K $\alpha, \beta$, and $\delta$ isoforms encoded by their corresponding genes PIK3CA, PIK3CB, and PIK3CD [9]. Irregular activation of the PI3K $\alpha / A K T$ signaling pathway has been observed in multiple human cancers [10]. The PIK3CA is catalyzed, over encrypted, and altered in human cancers [10]. Mutations of PI3K $\alpha$ domains, the helical (E545K and E542K) and kinase (H1047R), are identified in breast, brain, GIT, and uterus cancers [11-14]. These carcinogenic transformations deform PI3K $\alpha$ trajectories and thus in turn motivate researchers to design and develop selective PI3K $\alpha$ inhibitors [13]. The ubiquity of PI3K $\alpha$ and PTEN alterations in diverse human cancers highlights PI3K $\alpha$ as an attractive target for anticancer drug design $[15,16]$.

Applying pharmacophore modeling and database screening against the national cancer institute (NCI) database [17], we previously revealed N-benzyl-4-hydroxy-2-quinolone 
-3- carboxamide (1) as a lead inhibitor against the wild-type (WT) and mutant (MUT) H1047R PI3K $\alpha$ with $\mathrm{IC}_{50}$ values of $1.1 \mu \mathrm{M}$ and $0.73 \mu \mathrm{M}$, respectively (Figures 1 and 2) [18]. Furthermore, we identified the conformational changes of WT and MUT PI3K $\alpha$ that might be pinpointed to develop selective inhibitors [19].<smiles>O=C(NCc1ccccc1)c1c(O)c2ccccc2[nH]c1=O</smiles><smiles>[R]c1ccc(NC(=O)c2c(O)c3ccccc3[nH]c2=O)cc1</smiles>

2, $\mathrm{R}=\mathrm{H}$

3, $R=$ Substituent

Figure 1. Chemical structures of 1, 2, and 3.

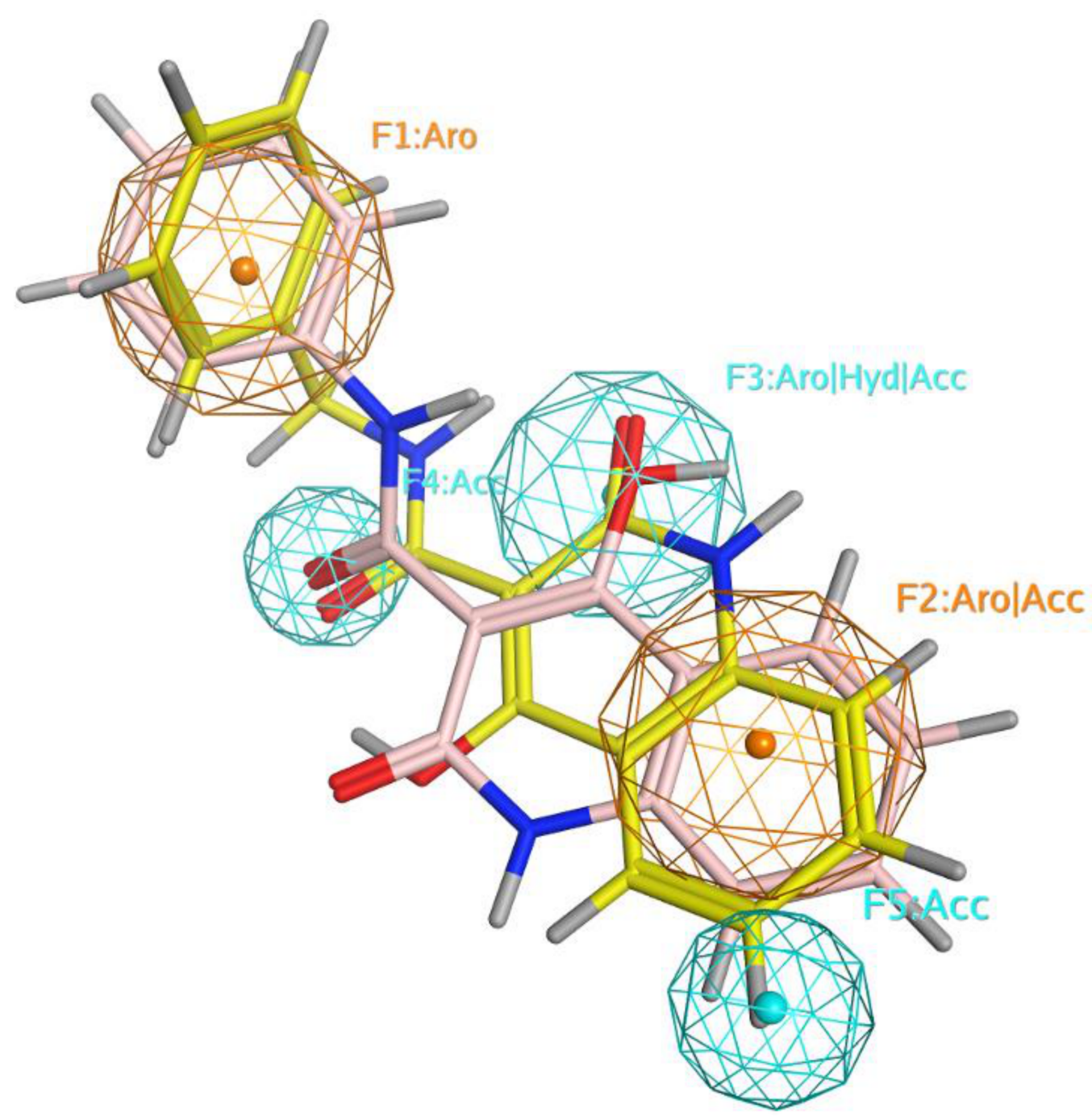

Figure 2. Phosphatidylinositol 3-kinase (PI3K $\alpha$ ) inhibitor pharmacophore model with compounds 1 (yellow color) and 2 (pink color). Picture captured by MOE [20].

In addition, we determined the significant binding residues of PI3K $\alpha$ s inhibitors by implementing molecular mechanics/generalized born surface area (MM/GBSA) procedure to calculate binding free energy for PI3K $\alpha$ molecular dynamic (MD) extracted coordinates [21]. Besides, ceaseless lead optimization tactics disclosed $N$-phenyl-4-hydroxy- 
2-quinolone-3-carboxamide derivatives as selective (MUT) H1047R PI3K $\alpha$ inhibitors illustrated by 2 [22]. Recently, we published a series of $N$-substituted- 4-hydroxy-2-quinolone3-carboxamides that demolished human colon carcinoma (HCT116) cell line differentiation and promoted apoptosis by catalyzing caspase- 3 activity and damaging cellular DNA represented by 3 [23]. Also, our continuous attempts released various core nucleus [24-30] targeting the kinase domain of PI3K $\alpha$.

In this respect, we designed and synthesized a series of N-phenyl-6-chloro-4-hydroxy2-quinolone-3-carboxamides to explore the effect of introducing chloro functionality on the inhibitory activity and to clarify the structure-activity relationship (SAR) of the analogues. Biological testing of the verified compounds and pan PI3K inhibitor (LY294002) was probed in vitro against human epithelial colorectal adenocarcinoma (Caco-2) and human colon carcinoma (HCT-116) cell lines.

\section{Results and Discussion}

\subsection{Chemistry}

Verified compounds (7-24) were designed to investigate the effect of attaching different motifs at the carboxamide link of 6-chloro-4-hydroxy-quinolinone core structure and their inhibitory activity. Reaction of $\mathbf{3}$ and $\mathbf{4}$ in sodium ethoxide under reflux produced the core nucleus 5 with $88 \%$ yield, as represented in Scheme 1. Thin-layer chromatography (TLC) application was recruited to monitor the reaction progress; the absence of a spot belonging to 3 highlighted the completeness of the reaction.<smiles>CCOC(=O)CC(=O)O[C+](C)CC</smiles>

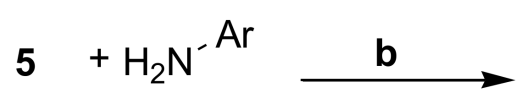

6a-v<smiles>O=C(N[Al])c1c(O)c2cc(Cl)ccc2[nH]c1=O</smiles>

7-24

Scheme 1. Conditions: (a): (i) $\mathrm{NaOC}_{2} \mathrm{H}_{5}, \mathrm{DMSO}, 145-150{ }^{\circ} \mathrm{C}, 72 \mathrm{~h}$. (ii) $0.3 \mathrm{M} \mathrm{HCl}$ (b): (i) $\mathrm{THF}, \mathrm{DMF}$, $150{ }^{\circ} \mathrm{C}, 48-72 \mathrm{~h}$.

Target compounds 7-27 have been generated by refluxing 5 with an excess of aromatic amine $\left(\mathrm{ArNH}_{2}\right)$ using DMF (dimethylformamide.), as depicted in Table 1 and Scheme 1. The disappearance of a spot of compound 5 on the TLC plate suggested that the reaction was finished. The identity of the chemical backbones was confirmed using IR, NMR and high-resolution mass spectra (HRMS). The elaborate experimental and spectroscopic data agree with the prospective structures. 
Table 1. Structures of synthesized derivatives of N-phenyl-6-chloro-4-hydroxy- 2-quinolone- 3carboxamide (7-24).

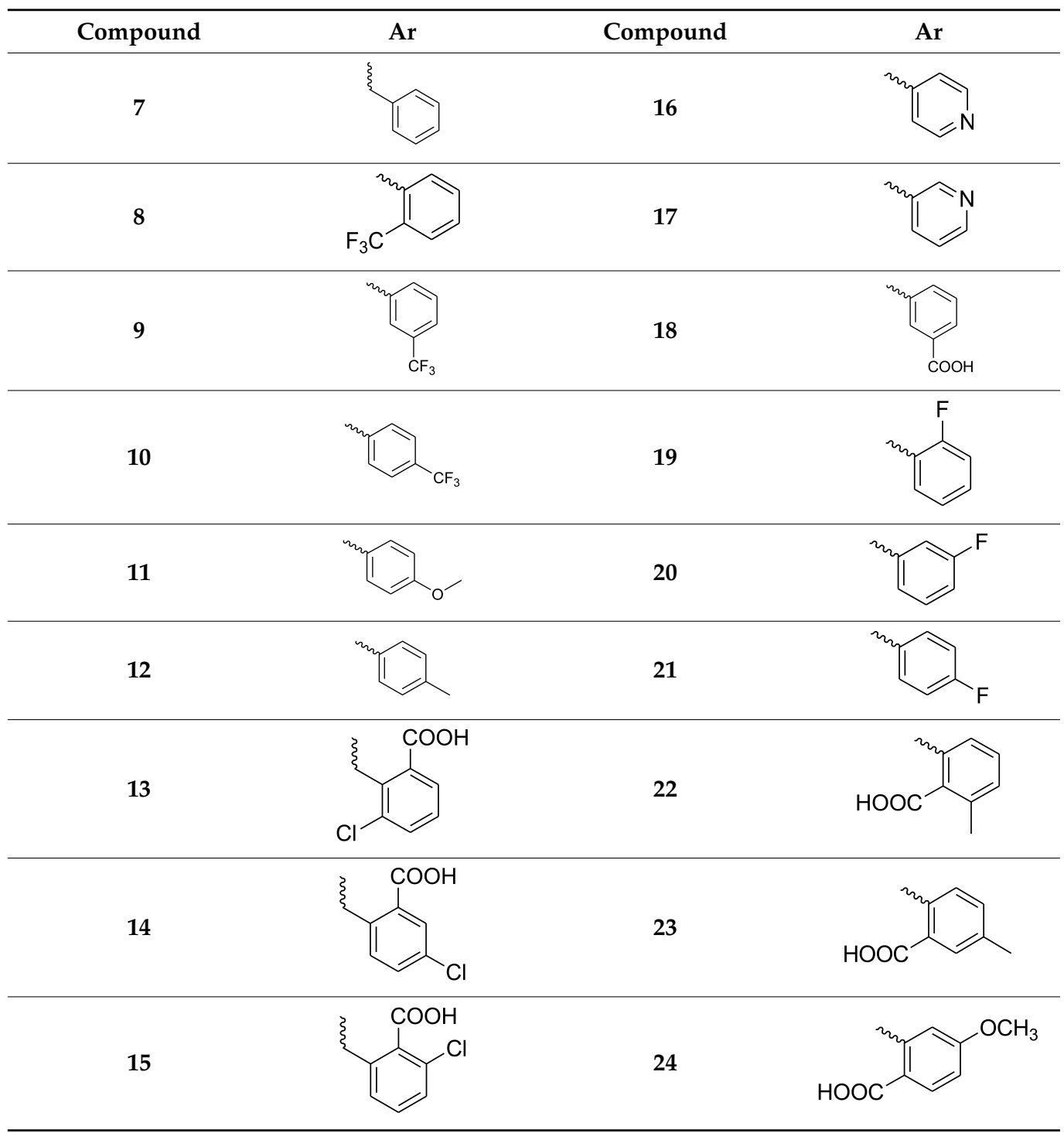

\subsection{Biological Evaluation of the Synthesized Compounds}

In order to evaluate the antiproliferative activity of the prospective compounds (5, 7-24) against the kinase domain of PI $3 \mathrm{~K} \alpha$, we examined their inhibitory activity in human epithelial colorectal adenocarcinoma (Caco-2) and the human colon cancer (HCT-116) cell line as shown in (Table 2). The epithelial colorectal adenocarcinoma (Caco-2) encodes the wild-type (WT) PI3K $\alpha$ [31-33]. The malignant (HCT-116) carcinoma expresses both wild-type (WT) and mutant (MUT) (H1047R) PI3K $\alpha$ [34]. Therefore, the difference in activity against Caco-2 and HCT-116 corresponds to MUT (H1047R) PI3K $\alpha$.

Screening against Caco-2 showed that compounds tailored with $o-\mathrm{CF}_{3}(8)$ or $m-\mathrm{CF}_{3}(9)$ provoke the activity suggesting that hydrophobic and/or H-bond interaction mediate(s) ligand $/$ PI $3 K \alpha$ complex formation. Similarly, the antiproliferative activity of $p-\mathrm{CF}_{3}(\mathbf{1 0})$ implies that hydrophobic and/or H-bond interaction guides (s) ligand/PI3K $\alpha$ interaction at $p$-position.

The antiproliferative activity of $p-\mathrm{OCH}_{3}(\mathbf{1 1})$ and $p-\mathrm{CH}_{3}(\mathbf{1 2})$ proclaims that oxygen atom places the $-\mathrm{CH}_{3}$ deeply in the binding pocket close to the hydrophobic lining, thus inducing the activity. Additionally, the activity of $p-\mathrm{CF}_{3}(\mathbf{1 0})$ and $p-\mathrm{CH}_{3}(\mathbf{1 2})$ indicates that $\mathrm{H}$-bond drives ligand/PI3K $\alpha$ interaction on $p$-position. Interestingly, elongation of the carboxamide side chain by one carbon exemplified by 7 enhances the activity assuming 
that the aromatic motif is buried deeply in the hydrophobic site. This result presumes that elongation of the carboxamide side chain (7) or tailoring the phenyl by $-\mathrm{OCH}_{3}(\mathbf{1 1})$ situates the hydrophobic motif in the hydrophobic cleft.

Table 2. Inhibitory activity $\left(\mathrm{IC}_{50} \mu \mathrm{M}\right)$ of 5, 7-24.

\begin{tabular}{cccccc}
\hline \multirow{2}{*}{ Compound } & \multicolumn{2}{c}{ IC $_{\mathbf{5 0}}(\mu \mathrm{M}) \pm$ SD } & \multirow{2}{*}{ Compound } & \multicolumn{2}{c}{ IC $_{\mathbf{5 0}}(\boldsymbol{\mu M}) \pm \mathbf{S D}$} \\
\cline { 2 - 3 } LY294002 & Caco-2 & HCT-116 & & & \\
\hline $\mathbf{5}$ & 7.4 & 6.5 & $\mathbf{1 5}$ & $61.0 \pm 4$ & $79.5 \pm 3$ \\
\hline $\mathbf{7}$ & $75.1 \pm 8$ & $78.4 \pm 9$ & $\mathbf{1 6}$ & $37.4 \pm 3$ & $8.9 \pm 1$ \\
\hline $\mathbf{8}$ & $13.8 \pm 1$ & $14.5 \pm 2$ & $\mathbf{1 7}$ & $35.8 \pm 4$ & $33.2 \pm 6$ \\
\hline $\mathbf{9}$ & $17.9 \pm 4$ & $14.5 \pm 2$ & $\mathbf{1 8}$ & $50.9 \pm 3$ & $3.3 \pm 0.2$ \\
\hline $\mathbf{1 0}$ & $20.3 \pm 2$ & $28.9 \pm 2$ & $\mathbf{1 9}$ & $17.0 \pm 4$ & $5.3 \pm 1$ \\
\hline $\mathbf{1 1}$ & $29.7 \pm 4$ & $37.0 \pm 6$ & $\mathbf{2 0}$ & $16.4 \pm 3$ & $27.0 \pm 5$ \\
\hline $\mathbf{1 2}$ & $14.1 \pm 1$ & $9.3 \pm 1$ & $\mathbf{2 1}$ & $18.9 \pm 2$ & $4.9 \pm 1$ \\
\hline $\mathbf{1 3}$ & $54.1 \pm 5$ & $56.3 \pm 5$ & $\mathbf{2 2}$ & $31.4 \pm 3$ & $50.2 \pm 6$ \\
\hline $\mathbf{1 4}$ & $81.4 \pm 6$ & $51.9 \pm 3$ & $\mathbf{2 3}$ & $66.5 \pm 7$ & $47.0 \pm 3$ \\
\hline & $14.1 \pm 1$ & $16.5 \pm 1$ & $\mathbf{2 4}$ & $23.0 \pm 2$ & $10.5 \pm 1$ \\
\hline
\end{tabular}

Tailoring the carboxamide side chain with substituted benzoic acid moiety (13, 14, and 15) reveals that $\mathrm{H}$-bond mediates ligand/PI3K $\alpha$ binding on $o$-and $m$-positions and thus in turn provides an explanation for the activity of $\mathbf{8}$ and $\mathbf{9}$. Furthermore, the activity of 14 suggests that the carboxylic group on $o$-position might be involved in intra H-bond generating a conformer that better orientates the analogue in the binding domain. Also, the activity of $\mathbf{1 3}, \mathbf{1 4}$, and $\mathbf{1 5}$ anticipates the substantial effect of choloro motif on better accommodation in the binding cleft. Introducing a heterocyclic group on the side chain of carboxamide illustrated by (16 and 17) confirms the significance of the aromatic or heterocyclic group for better activity. Additionally, the nitrogen atom in pyridine provides H-bond acceptor and promotes water solubility and polarity.

The activity of $\mathbf{1 8}$ affirms the importance of substituted benzoic acid motif and declares that the ionized carboxylate anion might impede cell membrane permeability. Additionally, the activity of $\mathbf{1 8}$ provides a clue for the beneficial influence of choloro group on cell membrane permeability as exemplified by 13, 14, and 15. Attaching a fluorinated benzene moiety on carboxamide side chain $(\mathbf{1 9}, \mathbf{2 0}$, and $\mathbf{2 1})$ induces the activity interrogating that the fluoro moiety on $o^{-}, m^{-}$, and $p$-positions properly accommodates the binding site due to its small size. Introducing the methylated benzoic acid motif (22 and 23) elicits the activity inferring that hydrophobic interaction mediates ligand/PI3K $\alpha$ interaction on $o$-and $m$-positions corresponding to -COOH. Contrarily, methoxylated benzoic acid moiety (24) induces the activity implying that $\mathrm{H}$-bond and/or hydrophobic interaction on $p$-position, relatively to-COOH, drives ligand/PI3K $\alpha$ binding.

Screening against HCT-116 revealed that elongating the carboxamide side chain (7) induces the inhibitory activity inferring better accommodating in the binding domain. The biological data of $o-\mathrm{CF}_{3}(\mathbf{8}), m-\mathrm{CF}_{3}(\mathbf{9})$, and $p-\mathrm{CF}_{3}$ (10) declare that hydrophobic and/or $\mathrm{H}$ bond mediates ligand/PI3K $\alpha$ interaction on $o$-position. The inhibitory activity of $p-\mathrm{OCH}_{3}$ (11) anticipates that the oxygen atom might push the $-\mathrm{CH}_{3}$ properly in the binding domain. Furthermore, the activity of $p-\mathrm{CH}_{3}(\mathbf{1 2})$ confirms the significance of oxygen atom and provides further explanation for the activity of $p-\mathrm{OCH}_{3}(\mathbf{1 1})$. Additionally, the inhibitory activity of $p-\mathrm{CF}_{3}(\mathbf{1 0})$ and $p-\mathrm{CH}_{3}$ (12) elucidates the importance of H-bonding at the $p$ position. Attaching a substituted benzoic acid moiety on carboxamide side chain (13, 14, and 15) shows that the $p$-chloro moiety provokes the activity anticipating a favored conformation is mediated by intra-H-bond between - $\mathrm{COOH}$ and the carboxamide motif. Tailoring the carboxamide side chain with pyridine-4-yl (16) induces the activity inferring 
that $\mathrm{H}$-bond and/or ionic interaction mediates $16 / \mathrm{PI} 3 \mathrm{~K} \alpha$ complex formation. Additionally, the activity of pyridine-3-yl (17) affirms the significance of pyridine-4-yl on inducing the inhibitory activity.

Attaching 3-benzoic acid moiety (18) elicits the activity suggesting that $\mathrm{H}$-bond and/or ionic interaction mediates ligand/PI3K $\alpha$ interaction. Incorporating a fluorinated benzene moiety $(\mathbf{1 9}, \mathbf{2 0}$, and 21) shows that the $o$-and $p$-fluoro analogs mediate $\mathrm{H}$-bond with key binding residues. Attaching a methylated benzoic acid motif (22 and 23) suggests that the intra- $\mathrm{H}$ bond offered by $-\mathrm{COOH}$ and the carboxamide motif generates a conformer that impedes their proper orientation in the binding domain. The activity of methoxylated benzoic acid moiety (24) declares that the oxygen atom might push $-\mathrm{CH}_{3}$ in the binding sites and the existence of $-\mathrm{COOH}$ might provide an intra-H-bond that orientates 24 properly in the binding site. Furthermore, the difference in the biological activity of 16, 18, 19, 21, and 24 against HCT-116 proclaims that selectivity is attained. Finally, the activity of 5 against Caco-2 and HCT-116 cell lines emphasizes the significance of substituted carboxamide motif.

Noting that the probed cell lines express both WT and MUT PI3K $\alpha$ s, separating either enzyme is strongly advised to validate the suppressive activity against isolated PI3K $\alpha$. Future confirmation should be accomplished by silencing either gene to explore the antiproliferative mechanism against each $\mathrm{PI} 3 \mathrm{~K} \alpha$.

The effects of compounds (18 and 19) on the PI3K/AKT signaling pathway were investigated using qPCR. The relative gene expression of PI3K, AKT, and BAD (BCL2 Associated Agonist of Cell Death) was significantly changed by treatment with either compound $(0.5 \mu \mathrm{M})$ in a manner consistent with the positive control treatment $(0.5 \mu \mathrm{M})$ (Figure 3). A substantial reduction in PI3K and AKT gene expression was observed upon treatment with 18, 19, or the positive control LY-294002. On the other hand, the expression of the pro-apoptotic gene BAD was significantly increased in treated cells (for all tested compound including the positive control) when compared to the negative control where there was no treatment applied.

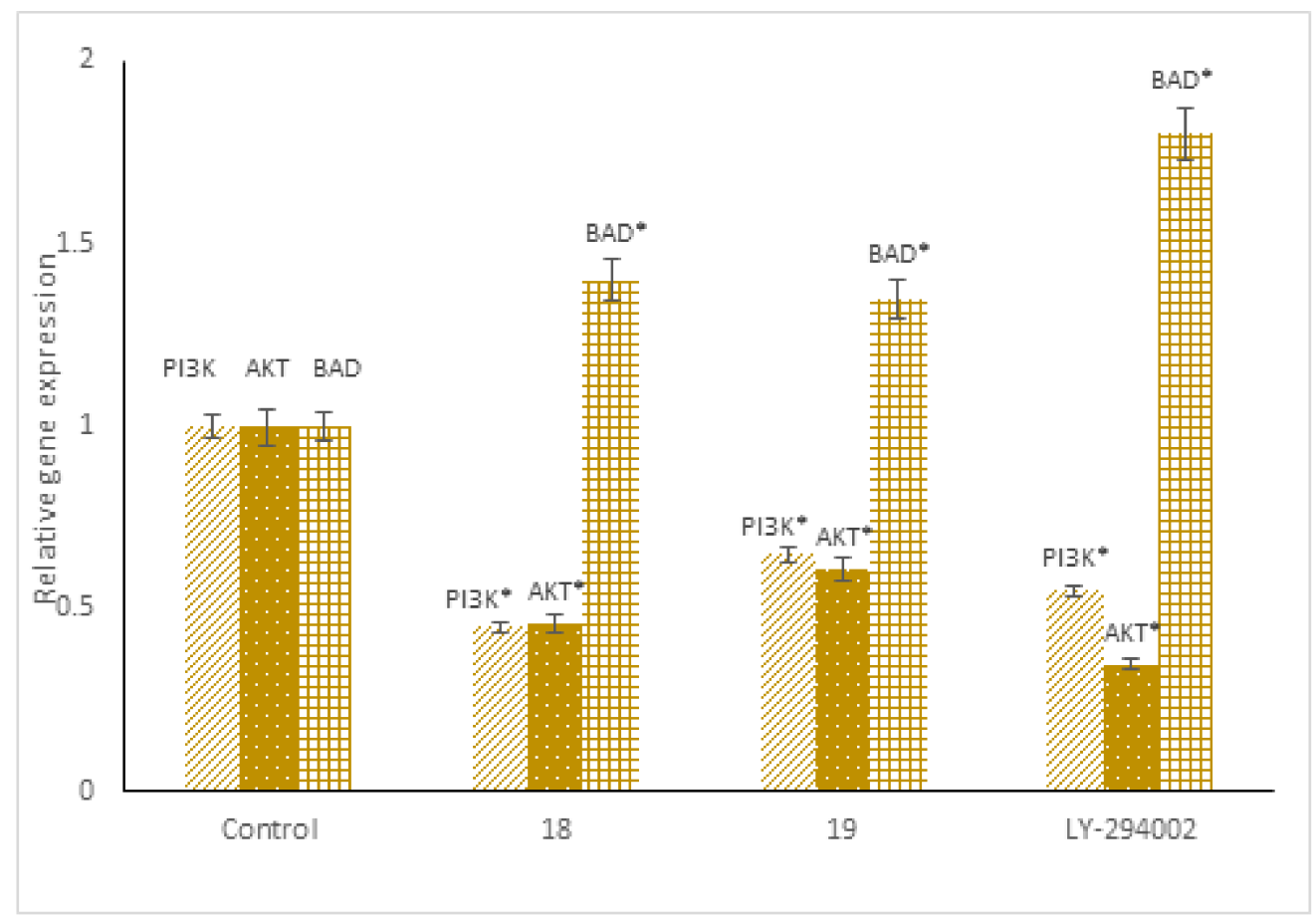

Figure 3. Relative gene expression of PI3K, AKT, and BAD in HCT116 cells after treatment with Compounds 18 and 19 and the positive control LY-294002. Bars represent mean values \pm SEM (lines) of three replicates. Asterisks represent significant change relative to the negative control $\left({ }^{*} p<0.05\right)$. 


\subsection{Computational Studies}

\subsubsection{Molecular Docking}

In order to discuss the anticancer activity of the synthesized compounds (5 and 7-24) in human colon carcinoma (HCT-116) and (Caco-2) cell lines, we recruited the co-ordinates of native (PDB ID: 2RD0) [9] and mutant H1047R (PDB ID: 3HHM) [35] PI3K $\alpha$ to determine the structural basis of $\mathrm{PI} 3 \mathrm{~K} \alpha /$ ligand interaction. In order to probe the binding interaction of PI3K $\alpha$ and the verified compounds (5 and 7-24) in the PI3K $\alpha$ kinase domain, we accomplished induced-fit docking (IFD) [36-38] studies against 2RD0 and 3HHM. IFD data demonstrate that 5 and 7-24 accommodate PI3K $\alpha$ s kinase domains (Figure 4A). Indeed, the docked geometry of $\mathbf{1 0}$ overlays the co-ordinate of $\mathrm{X} 6 \mathrm{~K}$ in the PI3K $\alpha$ kinase site (PDB ID: 4L23) [39] (Figure 4B).

A

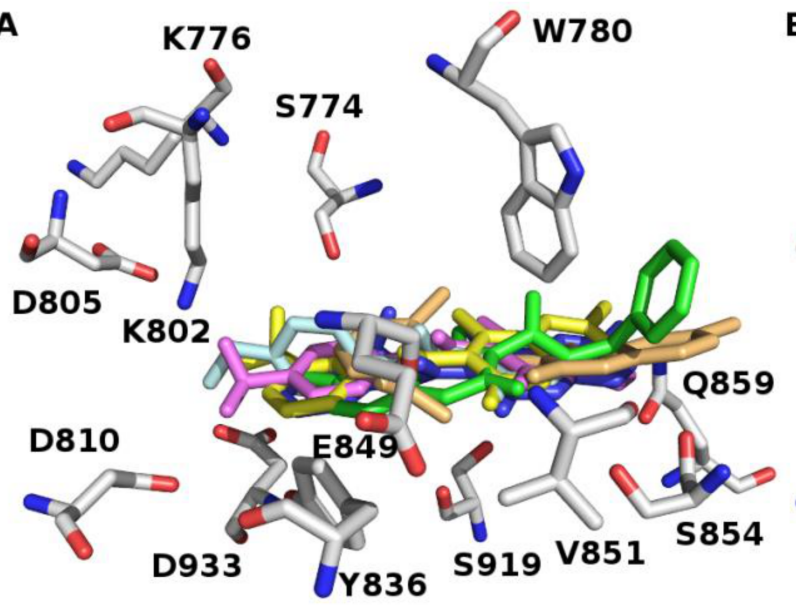

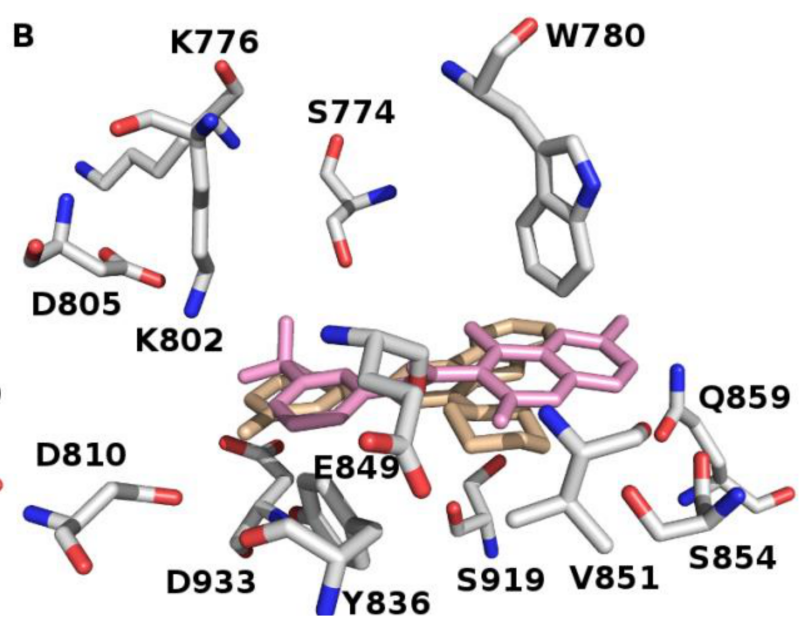

Figure 4. Kinase domain of (A) 2RD0 accommodating the IF docked geometries of some of the verified molecules and (B) superposing of the IF docked pose of $\mathbf{1 0}$ (pink color) and native pose of (X6K) (gold color). Some of the key binding residues are presented and $\mathrm{H}$ atoms are invisible for clarification. Picture made by PYMOL [38].

The IFD approach explores the structural changes in proteins in this way: ligands are docked to a protein's binding domain by Glide docking [36-38] and the top ligand conformation is minimized together with PI3K $\alpha$ binding cleft by the Prime algorithm [38]. Next, a redocking protocol is performed against the minimized PI3K $\alpha$. Accordingly, protein flexibility is investigated during the docking procedure. The synthesized core structures make H-bond with S774, A775, K776, W780, E798, K802, D810, Y836, V851, N853, S854, N920, and D933 (Table 3) (Figure 5). Additionally, other computational $[19,21-25,28,29,40]$ and experimental studies [9] highlighted the importance of these amino acids in PI3K $\alpha /$ ligand complex formation.

Remarkably, 5, 7-24 showed an affinity against both WT and MUT (H1047R) PI3K $\alpha$. Fortunately, higher binding affinity against $3 \mathrm{HHM}$ was recorded for $\mathbf{1 2}$ and $\mathbf{1 5}$. Around 2 Kcal difference in binding energy against PI $3 \mathrm{~K} \alpha$ s might predict that this series is mutant selective. Furthermore, the dominance of S774 and K802 in ligand/PI3K $\alpha$ complex formation infers that the scaffold might be PI3K $\alpha$-selective inhibitors [19].

To evaluate the execution of the IFD algorithm, we compared the docked pose of X6K in WT PI3K $\alpha$ (PDB ID: 4L23) [39] to its native geometry in the crystal assembly. Figure 6 demonstrates the overlaying of the IFD-extracted X6K conformation and its native geometry in 4L23. The RMSD for heavy atoms of X6K between IFD-extracted docked conformation and the native pose was $0.169 \AA$. The result infers that IFD can determine the native geometry in crystal co-ordinates and prosperously anticipate the ligand binding pose. 
Table 3. Induced-fit docking (IFD) scores ( $\mathrm{Kcal} / \mathrm{mol})$ and $\mathrm{H}$-bond interactions against wild-type (WT) (2RD0) and mutant (MUT) (3HHM) PI3K $\alpha$.

\begin{tabular}{|c|c|c|c|c|}
\hline \multirow{2}{*}{ 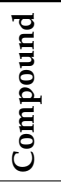 } & \multicolumn{2}{|r|}{ 2RD0 } & \multicolumn{2}{|r|}{ 3НHM } \\
\hline & Docking Score & Binding Residues & Docking Score & Binding Residues \\
\hline 5 & -8.11 & K802, Y836, D933 & -7.89 & W780, Y836, E849, D933 \\
\hline 7 & -8.38 & E849, V851, S854 & -7.19 & S774, D933 \\
\hline 8 & -9.01 & V851 & -8.16 & S774, D933 \\
\hline 9 & -8.99 & V851 & -8.37 & N920 \\
\hline 10 & -8.74 & V851, S854 & -9.09 & Y836, D933 \\
\hline 11 & -9.00 & K802, V851 & -8.74 & Y836, V851 \\
\hline 12 & -8.74 & V851, S854 & -10.73 & E849, V851, D933 \\
\hline 13 & -8.94 & E849, V851 & -8.32 & S774, A775, D933 \\
\hline 14 & -9.29 & K802, D933 & -8.20 & S774, D933 \\
\hline 15 & -7.65 & V851, Q859, E798 & -9.73 & S774, A775, K776, D933 \\
\hline 16 & -7.56 & V851 & -7.89 & S774, S919, D933 \\
\hline 17 & -8.83 & V851 & -8.56 & S774, D933, N920 \\
\hline 18 & -10.50 & $\begin{array}{l}\text { K802, D810, Y836, } \\
\text { V851, S854, D933 }\end{array}$ & -9.36 & S774, D933, N920 \\
\hline 19 & -8.44 & V851, Q859 & -7.89 & S774, D933, N920 \\
\hline 20 & -7.86 & V851 & -8.47 & S774, D933, N920 \\
\hline 21 & -8.46 & V851 & -8.18 & S774, D933, N920 \\
\hline 22 & -9.05 & S854, Q859 & -10.41 & S774, A775, K776, D933 \\
\hline 23 & -8.60 & V851, S854 & -9.20 & E849, Y836, D933 \\
\hline 24 & -10.33 & V851, N853, S854, Q859 & -9.02 & S774, Y836, D933 \\
\hline
\end{tabular}

A

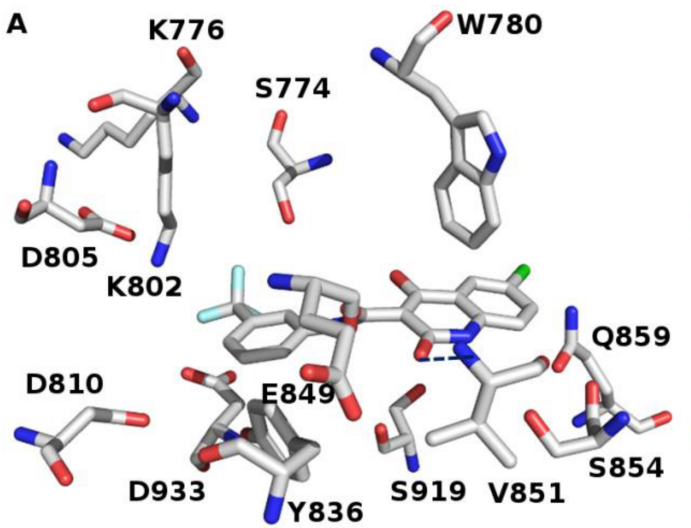

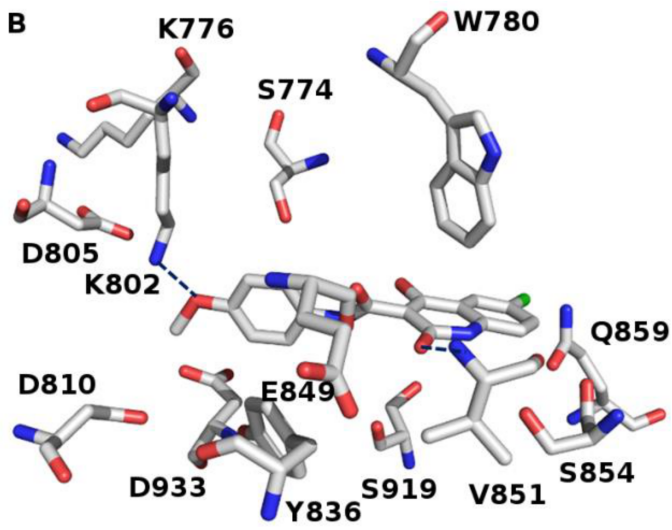

B

D933

Figure 5. Binding poses of (A) 9 and (B) 11 in the $2 \mathrm{RD} 0$ kinase site. The H-Bond is represented as a blue dotted line. $\mathrm{H}$ atoms are hidden for clarification. Picture made by PYMOL [38].

In order to inspect the binding groups of 7-24, we screened them against a reported pharmacophore model of active PI3K $\alpha$ inhibitors [18]. The core structure of 7-24 fit the functionalities of active PI3K $\alpha$ inhibitors (Figure 7), illustrated as (F1) indicating one aromatic ring; (F2) one aromatic or H-bond acceptor; (F3) one aromatic or hydrophobic or $\mathrm{H}$-bond acceptor; and either (F4) or (F5) one H-bond acceptor. The result interrogates the 
affinity of this scaffold against the PI3K $\alpha$ binding site. Additionally, the occupation of 7-24 in the kinase domain predicts their possible PI3K $\alpha$ antiproliferative activity.

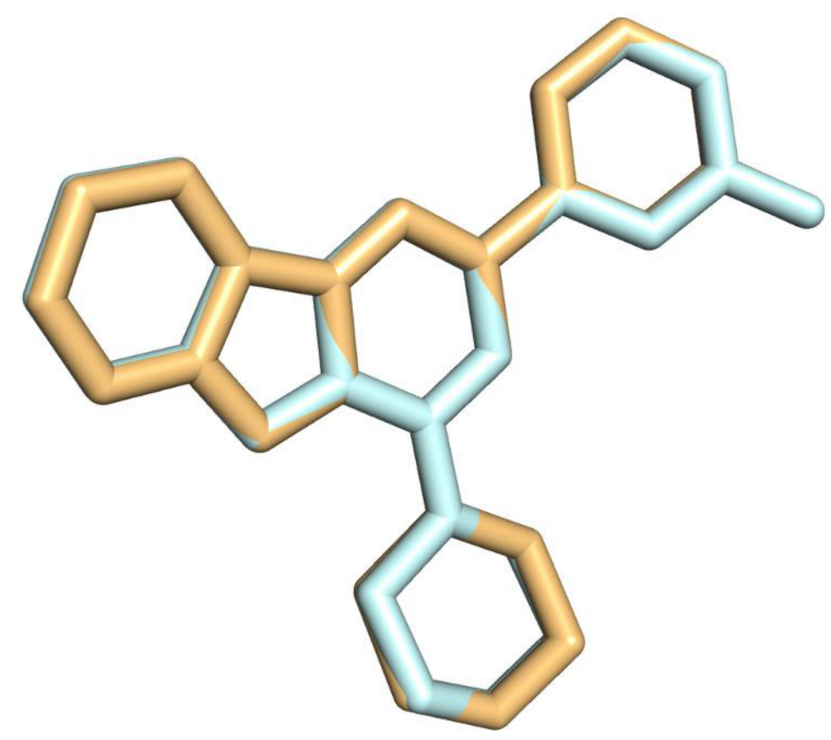

Figure 6. Superposition of the IFdocked $\mathrm{X} 6 \mathrm{~K}$ pose (blue color) and its native conformation (gold color) in 4L23. Picture made by PYMOL.

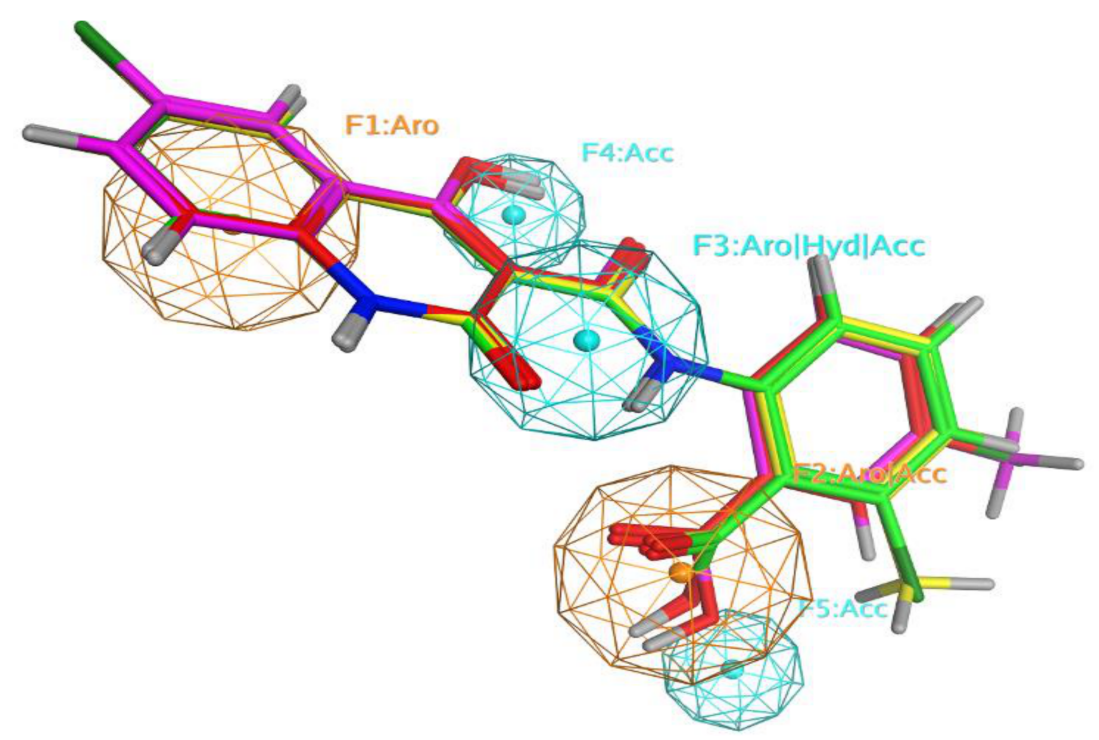

Figure 7. PI3K $\alpha$ inhibitors pharmacophore model with 14 (red color), 15 (green color), 22 (pink color), and 23 (yellow color).

\subsubsection{Descriptor Analysis}

Sixty-seven molecular descriptors comprising two main categories of alvaDecs [41] (i.e., drug-like indices, molecular properties and P_VSA-like descriptors) were calculated for molecules Mol.5-Mol.24. All descriptor values were then analyzed using principal component analysis. Our principal component analysis reveals that our compounds clustered into three main groups in the 3-D space formed by the first three principle components for the descriptor variance (Figure 8A). All calculated descriptors for all analyzed molecules are reported in Supplementary Table S1. Our analysis further revealed that our synthesized molecules differ in their lead-like and some drug-like properties as shown in Figure 8B. 
A

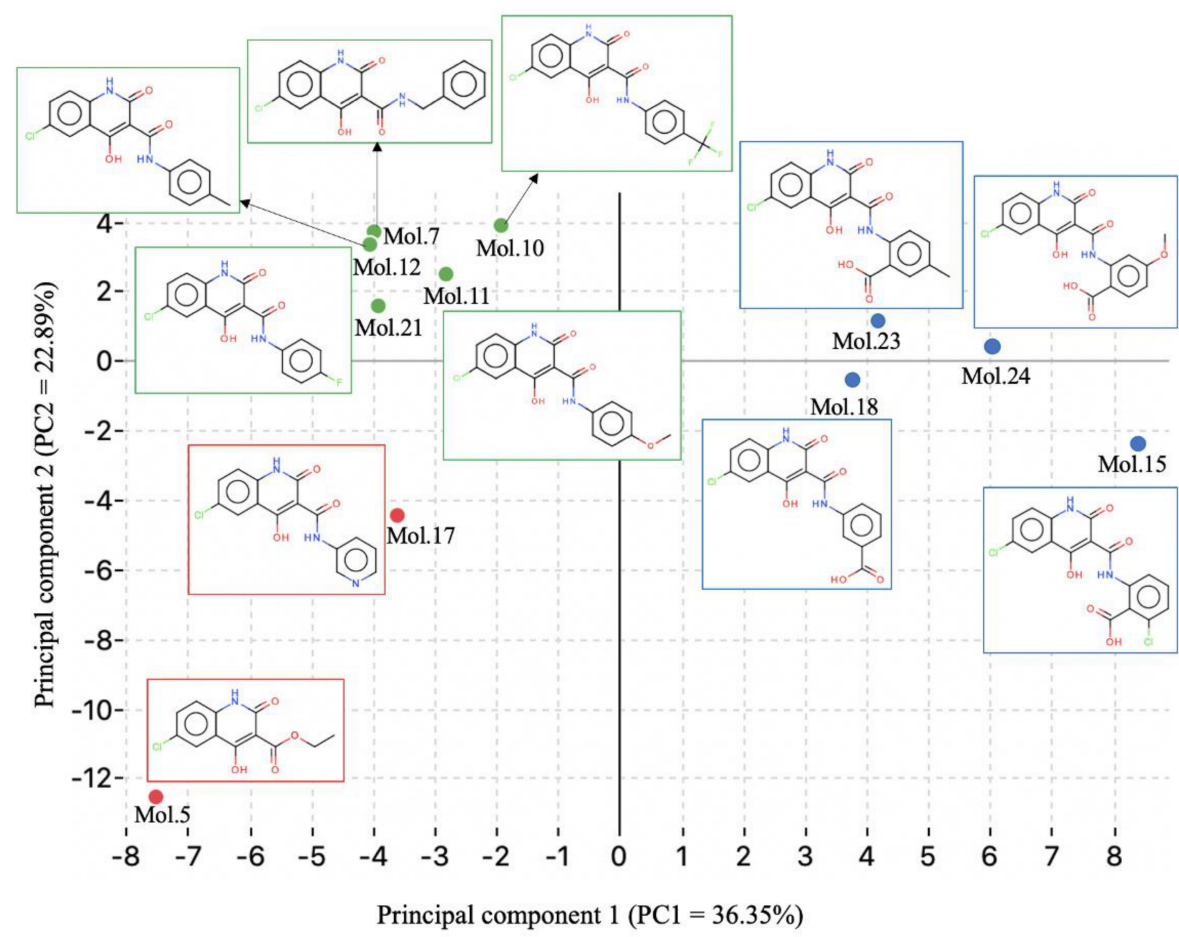

B

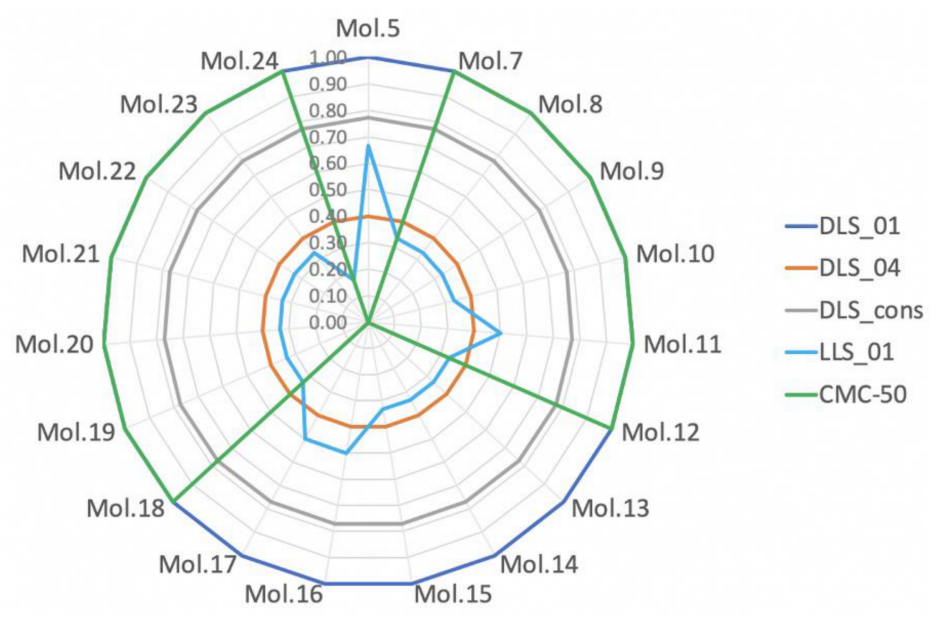

Figure 8. Molecular descriptor analysis. (A) A graphical 2D representation of the principal component analysis of molecular descriptors. PC1 explaining 36.35\% of the variation in descriptor values is on the x-axis, and PC2 explaining $22.89 \%$ of the variation in descriptor values is on the y-axis. Descriptor used for the analysis belong two major categories of molecular descriptors: (1) drug-like indices; (2) molecular properties and P_VSA-like descriptors. (B) Radar plot of a representative set of 5 molecular drug-like and lead-like molecular descriptors that showed variability for the same compound.

\section{Material and Methods}

\subsection{Chemistry}

Chemical reagents and solvents were of a highly purified grade and used right away lacking any purification technique. Reagents were bought from Alpha-Chemika (Mumbai, India), Acros Organics (Fair Lawn, NJ, USA), Sigma-Aldrich (St. Louis, MI, USA), and Scharlau Company (Barcelona, Spain). Rota vapor (1) model R-215 (Buchi, Switzerland) attached to vacuum pump model v-700 and water bath B-491 were recruited to evaporate ordinary solvents and vacuum controller v-855 was used to evaporate high boiling solvents such as DMSO and DMF. 
Melting points (MP) were recorded by Gallenkamp melting point apparatus. Hot plate and magnetic stirrer were delivered by vision scientific CO, LTD USA. Thin-layer chromatography (TLC) was conducted on $20 \times 20 \mathrm{~cm}^{2}$ with layer thickness $0.2 \mathrm{~mm}$ aluminum cards pre-coated with fluorescent silica gel GF254 DC (Fluka analytical, Buchs, Switzerland) and detected by UV light indicator (at 254 and / or $360 \mathrm{~nm}$ ).

Infrared (IR) spectra were recorded as, $\mathrm{KBr}$ discs, with a Shimadzu IR Affinity FTIR spectrophotometer. Nuclear magnetic resonance (NMR) ${ }^{1} \mathrm{H}$ - and ${ }^{13} \mathrm{C}-\mathrm{NMR}$ spectra were measured on Bruker NanoBay $400 \mathrm{MHz}$ spectrophotometer (the Hashemite University, Zarqa, Jordan). Chemical shifts were stated in $\delta$ (ppm) using TMS as an internal reference. High-resolution mass spectra (HRMS) were measured using a Bruker APEX-IV (7 Tesla) instrument. External calibration was performed using an arginine cluster at a mass range of $m / z 175-871$.

\subsection{Synthesis of Target Compounds}

\subsubsection{Ethyl 6-chloro-4-hydroxy-2-quinolone 3-carboxylate (5)}

A mixture of ethyl 2-amino-5-chloro benzoate (3) $(6.00 \mathrm{~g}, 30.06 \mathrm{mmol})$, an excess amount of diethylmalonate (4) $(48.10 \mathrm{~mL}, 300.60 \mathrm{mmol})$, and sodium ethoxide (6.25 g, $91.80 \mathrm{mmol}$ ) in $25 \mathrm{~mL}$ DMSO was prepared and refluxed for $96 \mathrm{~h}$. Completion of the reaction was observed by the absence of a spot of compound 3 on TLC. The generated solution was placed in an ice bath and then acidified with $0.3 \mathrm{M} \mathrm{HCl}$ reaching $\mathrm{pH}$ range of 4.5-5.0. A solid residue was formed, washed with water followed by $\mathrm{MeOH}(10 \mathrm{~mL})$, and then dried in a vacuum oven at $70{ }^{\circ} \mathrm{C}$ for $1 \mathrm{~h}$.

A beige powder; yield: $87.8 \%$; $\mathrm{R}_{f}=0.64\left(\mathrm{CHCl}_{3}: \mathrm{MeOH}-9.5: 0.5\right) ;$ m.p: $200-201{ }^{\circ} \mathrm{C}$; ${ }^{1} \mathrm{H}-\mathrm{NMR}\left(400 \mathrm{MHz}, \mathrm{DMSO}-d_{6+} \mathrm{NaOD}\right): \delta=3.41-3.53\left(\mathrm{~m}, 3 \mathrm{H},-\mathrm{CH}_{3}\right), 4.06-4.10(\mathrm{~m}, 2 \mathrm{H}$, $\left.-\mathrm{CH}_{2}\right), 6.88(\mathrm{~d}, J=8.0 \mathrm{~Hz}, 1 \mathrm{H}, \mathrm{Ar}-H), 6.97(\mathrm{~d}, J=8.0 \mathrm{~Hz}, 1 \mathrm{H}, \mathrm{Ar}-H), 7.71(\mathrm{~s}, 1 \mathrm{H}, \mathrm{Ar}-\mathrm{H}) \mathrm{ppm}$; ${ }^{13} \mathrm{C}-\mathrm{NMR}\left(100 \mathrm{MHz}, \mathrm{DMSO}-d_{6}\right): \delta=15.0$ (1C), $56.4(1 \mathrm{C}), 102.0$ (1C), 118.9 (1C), 124.1(1C), 124.2 (2C), 125.4 (1C), 127.9 (1C), 149.8 (1C), 172.9 (2C) ppm; IR (KBr disc): 3014, 2958, 2920, 2846, 1672, 1643, 1477, 1413, 1381, $1325 \mathrm{~cm}^{-1}$. High-resolution mass spectrum, $\mathrm{m} / \mathrm{z}$ : calculated 268.03766 for $\mathrm{C}_{12} \mathrm{H}_{11} \mathrm{ClNO}_{4}[\mathrm{M}+\mathrm{H}]^{+}$; found 268.03786 .

\subsubsection{N-benzyl 6-chloro-4-hydroxy-2-quinolone-3-carboxamide (7)}

A mixture of ethyl 6-chloro-4-hydroxy-2-quinolone-3-carboxylate (5) (1.00 g, $3.74 \mathrm{mmol})$ and benzyl amine (6a) $(1.20 \mathrm{~g}, 11.20 \mathrm{mmol})$ was prepared in THF $(25 \mathrm{~mL})$. A few drops of DMF were added to the solution and refluxed for $72 \mathrm{~h}$. Reaction progress was monitored by the absence of a spot of $\mathbf{5}$ on TLC and a precipitate appearance at RT. A solid residue was formed, washed with $\mathrm{H}_{2} \mathrm{O}, \mathrm{MeOH}$, and THF, and then dried in a vacuum oven at $70{ }^{\circ} \mathrm{C}$ for $1 \mathrm{~h}$.

A white powder; yield: $52.9 \% ; \mathrm{R}_{f}=0.8\left(\mathrm{CHCl}_{3}: \mathrm{MeOH}-9.5: 0.5\right)$; m.p: $360-362{ }^{\circ} \mathrm{C}$; ${ }^{1} \mathrm{H}-\mathrm{NMR}\left(400 \mathrm{MHz}\right.$, DMSO- $\left.d_{6+} \mathrm{NaOD}\right): \delta=3.53\left(\mathrm{~s}, 2 \mathrm{H},-\mathrm{CH}_{2}\right), 6.94(\mathrm{~d}, J=8.4 \mathrm{~Hz} 2 \mathrm{H}, \mathrm{Ar}-\mathrm{H})$, 7.04-7.07 (m, 2H, Ar-H), 7.44-7.45 (m, 1H, Ar-H), 7.57 (d, J = 7.2 Hz 1H, Ar-H), 7.78 (s, $1 \mathrm{H}, \mathrm{Ar}-H), 8.41(\mathrm{~d}, J=7.6 \mathrm{~Hz}, 1 \mathrm{H}, \mathrm{Ar}-H) \mathrm{ppm} ;{ }^{13} \mathrm{C}-\mathrm{NMR}\left(100 \mathrm{MHz}, \mathrm{DMSO}-d_{6}\right): \delta=100.5$ (1C), 119.4 (1C), 121.5 (1C), 124.4 (1C), 124.5 (1C), 125.7 (2C), 125.8 (1C), 132.4 (2C), 139.6 (1C), 149.6 (2C), 170.1 (2C), 174.0 (1C), 176.8 (1C) ppm; IR (KBr disc) 3192, 3078, 2918, 1666, $1633,1458,1415,1371,1323,1282 \mathrm{~cm}^{-1}$. High-resolution mass spectrum, $m / z$ : calculated 329.06930 for $\mathrm{C}_{17} \mathrm{H}_{14} \mathrm{ClN}_{2} \mathrm{O}_{3}[\mathrm{M}+\mathrm{H}]^{+}$; found 329.06984.

\subsection{3. $\mathrm{N}$-(2-(trifluoromethyl) phenyl)-6-chloro-4-hydroxy-2-quinolone-3-carboxamide (8)}

A mixture of ethyl 6-chloro-4-hydroxy-2-quinolone-3-carboxylate (5) $(1.00 \mathrm{~g}, 3.74 \mathrm{mmol})$ and 2-trifluromethyl aniline $(6 \mathbf{b})(1.80 \mathrm{~g}, 11.20 \mathrm{mmol})$ was prepared in THF $(25 \mathrm{~mL})$. A few drops of DMF were added to the solution and refluxed for $72 \mathrm{~h}$. Reaction progress was monitored by the absence of a spot of 5 on TLC and a precipitate appearance at RT. A solid residue was formed, washed with $\mathrm{H}_{2} \mathrm{O}, \mathrm{MeOH}$, and THF, and then dried in a vacuum oven at $70{ }^{\circ} \mathrm{C}$ for $1 \mathrm{~h}$. 
A white powder; yield: $55.6 \%, \mathrm{R}_{f}=0.78\left(\mathrm{CHCl}_{3}\right.$ : MeOH- 9.5:0.5); m.p: $294-296{ }^{\circ} \mathrm{C}$; ${ }^{1} \mathrm{H}-\mathrm{NMR}\left(400 \mathrm{MHz}, \mathrm{DMSO}-d_{6+} \mathrm{NaOD}\right): \delta=6.94-6.96(\mathrm{~m}, 1 \mathrm{H}, \mathrm{Ar}-\mathrm{H}), 7.05-7.08(\mathrm{~m}, 1 \mathrm{H}$, Ar- $H), 7.21(\mathrm{~d}, J=8.0 \mathrm{~Hz}, 1 \mathrm{H}, \mathrm{Ar}-H), 7.4(\mathrm{t}, J=8.0,4.0 \mathrm{~Hz}, 1 \mathrm{H}, \mathrm{Ar}-H), 7.76-7.81(\mathrm{~m}, 1 \mathrm{H}$, Ar- $H$ ), 8.25 (s, $1 \mathrm{H}, \mathrm{Ar}-H)$ ppm; ${ }^{13} \mathrm{C}-\mathrm{NMR}\left(100 \mathrm{MHz}, \mathrm{DMSO}-d_{6}\right): \delta=100.8(1 \mathrm{C}), 119.7(1 \mathrm{C})$, 120.9 (1C), $123.1(2 \mathrm{C}), 123.6$ (1C), 124.3 (2C), 124.4 (1C), 124.7 (1C), 126.3 (1C), 127.7 (1C), 129.9 (1C), 149.3 (1C), 170.2 (1C), 173.7 (1C), 176.6 (1C) ppm; IR (KBr disc): 3171, 3074, 3018, $1660,1570,1458,1417,1375,1332 \mathrm{~cm}^{-1}$. High-resolution mass spectrum, $m / z$ : calculated 383.04103 for $\mathrm{C}_{17} \mathrm{H}_{11} \mathrm{ClF}_{3} \mathrm{~N}_{2} \mathrm{O}_{3}[\mathrm{M}+\mathrm{H}]^{+}$; found 383.04151.

\subsubsection{N-(3-(trifluoromethyl)phenyl)-6-chloro-4-hydroxy-2-quinolone-3-carboxamide (9)}

A mixture of ethyl 6-chloro-4-hydroxy-2-quinolone-3-carboxylate (5) $(1.00 \mathrm{~g}, 3.74 \mathrm{mmol})$ and 3-trifluromethyl aniline $(6 \mathrm{c})(1.80 \mathrm{~g}, 11.20 \mathrm{mmol})$ was prepared THF $(25 \mathrm{~mL})$. A few drops of DMF were added to the solution and refluxed for $72 \mathrm{~h}$. Reaction progress was monitored by the absence of a spot of 5 on TLC and a precipitate appearance at RT. A solid residue was formed, washed with $\mathrm{H}_{2} \mathrm{O}, \mathrm{MeOH}$, and THF, and then dried in a vacuum oven at $70{ }^{\circ} \mathrm{C}$ for $1 \mathrm{~h}$.

A pale yellow powder; yield: $70.9 \%, \mathrm{R}_{f}=0.75\left(\mathrm{CHCl}_{3}: \mathrm{MeOH}-9.5: 0.5\right)$; m.p: $313-$ $314{ }^{\circ} \mathrm{C} ;{ }^{1} \mathrm{H}-\mathrm{NMR}\left(400 \mathrm{MHz}, \mathrm{DMSO}-d_{6+} \mathrm{NaOD}\right): \delta=6.94-6.99(\mathrm{~m}, 2 \mathrm{H}, \mathrm{Ar}-\mathrm{H}), 7.07(\mathrm{dd}, J=$ $2.8,2.8 \mathrm{~Hz}, 1 \mathrm{H}, \mathrm{Ar}-H), 7.52(\mathrm{~d}, J=8.4 \mathrm{~Hz}, 1 \mathrm{H}, \mathrm{Ar}-H), 7.71-7.81(\mathrm{~m}, 2 \mathrm{H}, \mathrm{Ar}-H), 7.87(\mathrm{~d}, J=$ $8.4 \mathrm{~Hz}, 1 \mathrm{H}, \mathrm{Ar}-H)$ ppm; ${ }^{13} \mathrm{C}-\mathrm{NMR}\left(100 \mathrm{MHz}, \mathrm{DMSO}-d_{6}\right): \delta=100.8(1 \mathrm{C}), 119.9$ (1C), 120.8 (1C), 121.14 (1C), 123.13 (2C), 123.5 (1C), 123.9 (1C), 124.4 (1C), 124.8 (1C), 125.8 (1C), 126.5 (1C), 145.4 (1C), 149.4 (1C), 170.3 (1C), 172.5 (1C), 173.9 (1C), 178.8 (1C) ppm; IR (KBr disc): 3036, 2964, 2902, 1658, 1602, 1467, 1415, 1375, $1325 \mathrm{~cm}^{-1}$. High-resolution mass spectrum, $m / z$ : calculated 383.04103 for $\mathrm{C}_{17} \mathrm{H}_{11} \mathrm{ClF}_{3} \mathrm{~N}_{2} \mathrm{O}_{3}[\mathrm{M}+\mathrm{H}]^{+}$; found 383.04178.

\subsection{5. $\mathrm{N}$-(4-(trifluoromethyl)phenyl)-6-chloro-4-hydroxy-2-quinolone-3-carboxamide (10)}

A mixture of ethyl 6-chloro-4-hydroxy-2-quinolone-3-carboxylate (5) $(1.00 \mathrm{~g}, 3.74 \mathrm{mmol})$ and 4-trifluromethyl aniline (6d) $(1.80 \mathrm{~g}, 11.20 \mathrm{mmol})$ was prepared in THF $(25 \mathrm{~mL})$. A few drops of DMF were added to the solution and refluxed for $72 \mathrm{~h}$. Reaction progress was monitored by the absence of a spot of 5 on TLC and a precipitate appearance at RT. A solid residue was formed, washed with $\mathrm{H}_{2} \mathrm{O}, \mathrm{MeOH}$, and THF, and then dried in a vacuum oven at $70{ }^{\circ} \mathrm{C}$ for $1 \mathrm{~h}$.

A white powder; yield: $57.0 \%, \mathrm{R}_{f}=0.8\left(\mathrm{CHCl}_{3}: \mathrm{MeOH}-9.5: 0.5\right) ;$ m.p: $262-264{ }^{\circ} \mathrm{C}$; ${ }^{1} \mathrm{H}-\mathrm{NMR}\left(400 \mathrm{MHz}\right.$, DMSO- $\left.d_{6+} \mathrm{NaOD}\right): \delta=6.92-6.95(\mathrm{~m}, 1 \mathrm{H}, \mathrm{Ar}-H), 7.03-7.05(\mathrm{~m}, 1 \mathrm{H}, \mathrm{Ar}-\mathrm{H})$, 7.18-7. 21 (m, 1H, Ar-H), 7.27-7.35 (m, 2H, Ar-H), 7.76- (m, 1H, Ar-H) ppm; ${ }^{13} \mathrm{C}-\mathrm{NMR}$ $\left(100 \mathrm{MHz}, \mathrm{DMSO}-d_{6}\right): \delta=101.0(1 \mathrm{C}), 124.2(1 \mathrm{C}), 124.5(2 \mathrm{C}), 126.75(4 \mathrm{C}), 127.7(4 \mathrm{C}), 141.43$ (1C), 148.77 (1C), 171.86 (1C), 173.72 (1C), 175.7 (1C) ppm; IR (KBr disc): 3240, 3151, 2980, $1674,1599,1469,1437,1383,1329 \mathrm{~cm}^{-1}$. High-resolution mass spectrum, $m / z$ : calculated 383.04103 for $\mathrm{C}_{17} \mathrm{H}_{11} \mathrm{ClF}_{3} \mathrm{~N}_{2} \mathrm{O}_{3}[\mathrm{M}+\mathrm{H}]^{+}$; found 383.04113.

\subsubsection{N-(4-methoxyphenyl)-6-chloro-4-hydroxy-2-quinolone-3-carboxamide (11)}

A mixture of ethyl 6-chloro-4-hydroxy-2-quinolone-3-carboxylate (5) (1.00 g, $3.74 \mathrm{mmol})$ and 4-Anisidine (6e) $(1.38 \mathrm{~g}, 11.20 \mathrm{mmol})$ was prepared in THF $(25 \mathrm{~mL})$. A few drops of DMF were added to the solution and refluxed for $72 \mathrm{~h}$. Reaction progress was monitored by the absence of a spot of 5 on TLC and a precipitate appearance at RT. A solid residue was formed, washed with $\mathrm{H}_{2} \mathrm{O}, \mathrm{MeOH}$, and THF, and then dried in a vacuum oven at $70{ }^{\circ} \mathrm{C}$ for $1 \mathrm{~h}$.

A brown powder; yield: $75.1 \%, \mathrm{R}_{f}=0.8\left(\mathrm{CHCl}_{3}\right.$ : $\left.\mathrm{MeOH}-9.5: 0.5\right) ;$ m.p: $315-31{ }^{\circ} \mathrm{C}$; ${ }^{1} \mathrm{H}-\mathrm{NMR}\left(400 \mathrm{MHz}\right.$, DMSO- $\left.d_{6+} \mathrm{NaOD}\right): \delta=3.7\left(\mathrm{~s}, 3 \mathrm{H}, \mathrm{OCH}_{3}\right), 6.81(\mathrm{~d}, J=8.8 \mathrm{~Hz}, 2 \mathrm{H}, \mathrm{Ar}-\mathrm{H})$, 6.94-7. $06(\mathrm{~m}, 4 \mathrm{H}, \mathrm{Ar}-\mathrm{H}), 7.61(\mathrm{~d}, J=8.8 \mathrm{~Hz}, 2 \mathrm{H}, \mathrm{Ar}-\mathrm{H}), 7.80(\mathrm{~s}, 1 \mathrm{H}, \mathrm{Ar}-\mathrm{H}) \mathrm{ppm} ;{ }^{13} \mathrm{C}-\mathrm{NMR}$ $\left(100 \mathrm{MHz}, \mathrm{DMSO}-d_{6}\right): \delta=55.5(1 \mathrm{C}), 101.1(1 \mathrm{C}), 114.01(3 \mathrm{C}), 119.6$ (1C), $121.1(3 \mathrm{C}), 124.3(1 \mathrm{C})$, 124.4 (1C), 135.1 (1C), 149.1 (1C), 154.1 (1C), 169.7 (1C), 173.8 (1C), 175.9 (1C) ppm; IR (KBr disc): 3840, 3730, 1660, 1612, 1566, 1508, 1465, $1417 \mathrm{~cm}^{-1}$. High-resolution mass spectrum, $\mathrm{m} / z$ : calculated 345.06421 for $\mathrm{C}_{17} \mathrm{H}_{14} \mathrm{ClN}_{2} \mathrm{O}_{4}[\mathrm{M}+\mathrm{H}]^{+}$; found 345.06478 . 
3.2.7. N-p-tolyl-6-chloro-4-hydroxy-2-quinolone-3-carboxamide (12)

A mixture of ethyl 6-chloro-4-hydroxy-2-quinolone-3-carboxylate (5) (1.00 g, $3.74 \mathrm{mmol})$ and 4-toluidine (6f) $(1.20 \mathrm{~g}, 11.20 \mathrm{mmol})$ was prepared in THF $(25 \mathrm{~mL})$. A few drops of DMF were added to the solution and refluxed for $72 \mathrm{~h}$. Reaction progress was monitored by the absence of a spot of 5 on TLC and a precipitate appearance at RT. A solid residue was formed, washed with $\mathrm{H}_{2} \mathrm{O}, \mathrm{MeOH}$, and THF, and then dried in a vacuum oven at $70{ }^{\circ} \mathrm{C}$ for $1 \mathrm{~h}$.

An off white powder; yield: $69.5 \%, \mathrm{R}_{f}=0.8\left(\mathrm{CHCl}_{3}: \mathrm{MeOH}-9.5: 0.5\right) ; \mathrm{m} . \mathrm{p}: 333-334{ }^{\circ} \mathrm{C}$; ${ }^{1} \mathrm{H}-\mathrm{NMR}\left(400 \mathrm{MHz}, \mathrm{DMSO}-d_{6+} \mathrm{NaOD}\right): \delta=2.24\left(\mathrm{~s}, 3 \mathrm{H}, \mathrm{CH}_{3}\right), 6.93-6.96(\mathrm{~m}, 1 \mathrm{H}, \mathrm{Ar}-\mathrm{H})$, 7.01-7. 07 (m, 3H, Ar-H), 7.59-7.61 (m, 2H, Ar-H), 7.80-7.81 (m, 1H, Ar-H), ppm; ${ }^{13} \mathrm{C}-\mathrm{NMR}$ $\left(100 \mathrm{MHz}, \mathrm{DMSO}-d_{6}\right): \delta=20.9(1 \mathrm{C}), 101.1(1 \mathrm{C}), 124.3(3 \mathrm{C}), 124.5(2 \mathrm{C}), 128.6(1 \mathrm{C}), 129.3(3 \mathrm{C})$, 129.8 (1C), 139.32 (1C), 149.2 (1C), 169.9 (1C), 173.9 (1C), 176.9 (1C) ppm; IR (KBr disc): 3149 , 3020, 2974, 1658, 1602, 1508, 1467, 1415, $1371 \mathrm{~cm}^{-1}$. High-resolution mass spectrum, $\mathrm{m} / \mathrm{z}$ : calculated 329.06930 for $\mathrm{C}_{17} \mathrm{H}_{14} \mathrm{ClN}_{2} \mathrm{O}_{3}[\mathrm{M}+\mathrm{H}]^{+}$; found 329.06945 .

3.2.8. N-(5-chlorobenzoic acid)-6-chloro-4-hydroxy-2-quinolone-3-carboxamide (13)

A mixture of ethyl 6-chloro-4-hydroxy-2-quinolone-3-carboxylate (5) $(1.00 \mathrm{~g}, 3.74 \mathrm{mmol})$ and 2-amino 3-chloro benzoic acid $(\mathbf{6 g})(1.90 \mathrm{~g}, 11.20 \mathrm{mmol})$ was prepared together in THF $(25 \mathrm{~mL})$. A few drops of DMF were added to the solution and refluxed for $72 \mathrm{~h}$. Reaction progress was monitored by the absence of a spot of $\mathbf{5}$ on TLC and a precipitate appearance at RT. A solid residue was formed, washed with $\mathrm{H}_{2} \mathrm{O}, \mathrm{MeOH}$, and THF, and then dried in a vacuum oven at $70^{\circ} \mathrm{C}$ for $1 \mathrm{~h}$.

A pale yellow powder; yield: $86.2 \%, \mathrm{R}_{f}=0.26\left(\mathrm{CHCl}_{3}\right.$ : $\left.\mathrm{MeOH}-9.5: 0.5\right) ;$ m.p: 222 $224{ }^{\circ} \mathrm{C} ;{ }^{1} \mathrm{H}-\mathrm{NMR}\left(400 \mathrm{MHz}, \mathrm{DMSO}-d_{6}\right): \delta=16.27(\mathrm{~s}, 1 \mathrm{H},-\mathrm{OH}$ phenol), $13.22(\mathrm{~s}, 1 \mathrm{H},-\mathrm{COOH})$, 12.41 (s, 1H, Ar-NH), 12.24 (s, 1H, $-\mathrm{NH}$ amide), 7.81-7.87 (m, 3H, Ar-H), 7.34-7.55 (m, 3H, Ar- $H$ ) ppm; ${ }^{13} \mathrm{C}-\mathrm{NMR}\left(100 \mathrm{MHz}, \mathrm{DMSO}-d_{6}\right): \delta=96.9$ (1C), 97.5 (1C), $116.5(1 \mathrm{C}), 119.4$ (1C), 123.7 (1C), 128.2 (1C), 128.4 (1C), 129.3 (1C), 129.4 (1C), 130.7 (1C), 130.8 (1C), 131.3 (1C), 163.0 (1C), 167.14 (1C), 169.7 (1C), 170.0 (1C) ppm; IR (KBr disc): 3482, 3368, 3057, $1667,1586,1545,1458,1420,1314 \mathrm{~cm}^{-1}$. High-resolution mass spectrum, $m / z$ : calculated 393.00450 for $\mathrm{C}_{17} \mathrm{H}_{11} \mathrm{Cl}_{2} \mathrm{~N}_{2} \mathrm{O}_{5}[\mathrm{M}+\mathrm{H}]^{+}$; found 393.00398.

\subsubsection{N-(3-chlorobenzoic acid)-6-chloro-4-hydroxy-2-quinolone-3-carboxamide (14)}

A mixture of ethyl 6-chloro-4-hydroxy-2-quinolone-3-carboxylate (5) (1.00 g, $3.74 \mathrm{mmol})$ and 2-amino 5-chloro benzoic acid $(6 \mathbf{h})(1.90 \mathrm{~g}, 11.20 \mathrm{mmol})$ was prepared in THF $(25 \mathrm{~mL})$. A few drops of DMF were added to the solution and refluxed for $72 \mathrm{~h}$. Reaction progress was monitored by the absence of a spot of 5 on TLC and a precipitate appearance at RT. A solid residue was formed, washed with $\mathrm{H}_{2} \mathrm{O}, \mathrm{MeOH}$, and $\mathrm{THF}$, and then dried in a vacuum oven at $70{ }^{\circ} \mathrm{C}$ for $1 \mathrm{~h}$.

An off white powder; yield: $97.6 \%, \mathrm{R}_{f}=0.23\left(\mathrm{CHCl}_{3}: \mathrm{MeOH}-9.5: 0.5\right) ; \mathrm{m} . \mathrm{p}: 236-237^{\circ} \mathrm{C}$; ${ }^{1} \mathrm{H}-\mathrm{NMR}\left(400 \mathrm{MHz}, \mathrm{DMSO}-d_{6+} \mathrm{NaOD}\right): \delta=6.56(\mathrm{~d}, J=8.4,2 \mathrm{H}, \mathrm{Ar}-\mathrm{H}), 6.92-7.06(\mathrm{~m}, 1 \mathrm{H}$, Ar-H), 7.60-7.67 (m, 2H, Ar-H), 7.88 (s, $1 \mathrm{H}, \mathrm{Ar}-\mathrm{H}), 8.61$ (pseudo d, 1H, -NH-side chain), 7.97 $(\mathrm{d}, J=8.8 \mathrm{~Hz}, 1 \mathrm{H}, \mathrm{Ar}-H) \mathrm{ppm} ;{ }^{13} \mathrm{C}-\mathrm{NMR}\left(100 \mathrm{MHz}, \mathrm{DMSO}-d_{6}\right): \delta=117.3(2 \mathrm{C}), 117.7(2 \mathrm{C})$, 122.0 (2C), 129.9 (2C), 131.3 (2C), 138.7 (1C), 149.0 (2C), 170.1 (1C), 171.1 (1C), 173.5 (1C), 175.7 (1C) ppm; IR (KBr disc): 3502, 3470, 3387, 1672, 1585, 1548, 1483, 1419, $1296 \mathrm{~cm}^{-1}$. High-resolution mass spectrum, $m / z$ : calculated 393.00450 for $\mathrm{C}_{17} \mathrm{H}_{11} \mathrm{Cl}_{2} \mathrm{~N}_{2} \mathrm{O}_{5}[\mathrm{M}+\mathrm{H}]^{+}$; found 393.00489 .

\subsubsection{N-(2-chlorobenzoic acid)-6-chloro-4-hydroxy-2-quinolone-3-carboxamide (15)}

A mixture of ethyl 6-chloro-4-hydroxy-2-quinolone-3-carboxylate (5) $(1.00 \mathrm{~g}, 3.74 \mathrm{mmol})$ and 2-amino 6-chloro benzoic acid $(6 \mathbf{6 i})(1.90 \mathrm{~g}, 11.20 \mathrm{mmol})$ was prepared in THF $(25 \mathrm{~mL})$. A few drops of DMF were added to the solution and refluxed for $72 \mathrm{~h}$. Reaction progress was monitored by the absence of a spot of 5 on TLC and a precipitate appearance at RT. A solid residue was formed, washed with $\mathrm{H}_{2} \mathrm{O}, \mathrm{MeOH}$, and THF, and then dried in a vacuum oven at $70{ }^{\circ} \mathrm{C}$ for $1 \mathrm{~h}$. 
An off white powder; yield: $38.7 \%, \mathrm{R}_{f}=0.26\left(\mathrm{CHCl}_{3}: \mathrm{MeOH}-8: 2\right)$; m.p: $310-312{ }^{\circ} \mathrm{C}$; ${ }^{1} \mathrm{H}-\mathrm{NMR}\left(400 \mathrm{MHz}, \mathrm{DMSO}-d_{6}\right): \delta=7.28(\mathrm{t}, J=8.8 \mathrm{~Hz}, 1 \mathrm{H}, \mathrm{Ar}-H), 7.40-7.53(\mathrm{~m}, 1 \mathrm{H}, \mathrm{Ar}-H)$, $7.71(\mathrm{~d}, J=2 \mathrm{~Hz}, 1 \mathrm{H}, \mathrm{Ar}-H), 7.76(\mathrm{~d}, J=8.4 \mathrm{~Hz}, 1 \mathrm{H}, \mathrm{Ar}-H), 7.83-7.87(\mathrm{~m}, 1 \mathrm{H}, \mathrm{Ar}-H), 7.91-8.01$ (m, 2H, Ar-H \& -NH-side chain), 11.34-11.53 (m, 1H, -NH-ring), 12.15 (s, 1H, -COOH), 12.64 $(\mathrm{s}, 1 \mathrm{H},-\mathrm{OH}) \mathrm{ppm} ;{ }^{13} \mathrm{C}-\mathrm{NMR}\left(100 \mathrm{MHz}, \mathrm{DMSO}-d_{6}\right): \delta=115.6(1 \mathrm{C}), 122.2(1 \mathrm{C}), 123.2(2 \mathrm{C})$, 123.5 (1C), 124.7 (1C), 125.6 (1C), 126.3 (1C), 126.6 (2C), 127.3 (1C), 128.8 (1C), $138.1(1 \mathrm{C})$, 138.8 (1C), 161.7 (1C), 162.9 (1C), 163.7 (1C) ppm; IR (KBr disc): 3132, 2980, 2899, 1691, 1645, $1543,1460,1373,1317 \mathrm{~cm}^{-1}$. High-resolution mass spectrum, $\mathrm{m} / z$ : calculated 393.00450 for $\mathrm{C}_{17} \mathrm{H}_{11} \mathrm{Cl}_{2} \mathrm{~N}_{2} \mathrm{O}_{5}[\mathrm{M}+\mathrm{H}]^{+}$; found 393.00425.

\subsubsection{N-(pyridine-4-yl)-6-chloro-4-hydroxy-2-quinolone-3-carboxamide (16)}

A mixture of ethyl 6-chloro-4-hydroxy-2-quinolone-3-carboxylate (5) $(1.00 \mathrm{~g}, 3.74 \mathrm{mmol})$ and 4-amino pyridine $(\mathbf{6 j})(1.10 \mathrm{~g}, 11.20 \mathrm{mmol})$ was prepared in THF $(25 \mathrm{~mL})$. A few drops of DMF were added to the solution and refluxed for $72 \mathrm{~h}$. Reaction progress was monitored by the absence of a spot of 5 on TLC and a precipitate appearance at RT. A solid residue was formed, washed with $\mathrm{H}_{2} \mathrm{O}, \mathrm{MeOH}$, and THF, and then dried in a vacuum oven at $70{ }^{\circ} \mathrm{C}$ for $1 \mathrm{~h}$.

A pale pink powder; yield: $50.1 \%, \mathrm{R}_{f}=0.1\left(\mathrm{CHCl}_{3}: \mathrm{MeOH}-9.5: 0.5\right)$; m.p: $312-314{ }^{\circ} \mathrm{C}$; ${ }^{1} \mathrm{H}-\mathrm{NMR}\left(400 \mathrm{MHz}\right.$, DMSO- $\left.d_{6+} \mathrm{NaOD}\right): \delta=6.98(\mathrm{~d}, J=8.8 \mathrm{~Hz}, 2 \mathrm{H}, \mathrm{Ar}-H), 7.08(\mathrm{dd}, J=2.8$, $2.8 \mathrm{~Hz} 2 \mathrm{H}, \mathrm{Ar}-H), 7.67(\mathrm{~d}, J=3.2 \mathrm{~Hz}, 2 \mathrm{H}, \mathrm{Ar}-\mathrm{H}), 7.81(\mathrm{~s}, 1 \mathrm{H}, \mathrm{Ar}-\mathrm{H}), 8.23(\mathrm{~s}, 1 \mathrm{H},-\mathrm{NH}$-side chain) ppm; ${ }^{13} \mathrm{C}-\mathrm{NMR}\left(100 \mathrm{MHz}\right.$, DMSO- $\left.d_{6}\right): \delta=100.9(1 \mathrm{C}), 114.2(2 \mathrm{C}), 120.1(1 \mathrm{C}), 124.2$ (1C), 124.3 (1C), 124.7 (1C), 129.3 (1C), 148.14 (2C), 149.3 (1C), 150.0 (1C), 170.6 (1C), 173.5 (1C), 176.9 (1C) ppm; IR (KBr disc): 3068, 2987, 2912, 1676, 1583, 1537, 1425, 1377, 1240 $\mathrm{cm}^{-1}$. High-resolution mass spectrum, $m / z$ : calculated 316.04889 for $\mathrm{C}_{15} \mathrm{H}_{11} \mathrm{ClN}_{3} \mathrm{O}_{3}[\mathrm{M}+$ $\mathrm{H}]^{+}$; found 316.04824.

\subsubsection{2. $\mathrm{N}$-(pyridine-3-yl)-6-chloro-4-hydroxy-2-quinolone-3-carboxamide (17)}

A mixture of ethyl 6-chloro-4-hydroxy-2-quinolone-3-carboxylate (5) $(1.00 \mathrm{~g}, 3.74 \mathrm{mmol})$ and 3-amino pyridine $(6 \mathbf{k})(1.10 \mathrm{~g}, 11.20 \mathrm{mmol})$ was put together in THF $(25 \mathrm{~mL})$. A few drops of DMF were added to the solution and refluxed for $72 \mathrm{~h}$. Reaction progress was monitored by the absence of a spot of 5 on TLC and a precipitate appearance at RT. A solid residue was formed, washed with $\mathrm{H}_{2} \mathrm{O}, \mathrm{MeOH}$, and THF, and then dried in a vacuum oven at $70{ }^{\circ} \mathrm{C}$ for $1 \mathrm{~h}$.

A white powder; yield: $61.5 \%, \mathrm{R}_{f}=0.56\left(\mathrm{CHCl}_{3}: \mathrm{MeOH}-9.5: 0.5\right) ; \mathrm{m} . \mathrm{p}: 347-348{ }^{\circ} \mathrm{C}$; ${ }^{1} \mathrm{H}-\mathrm{NMR}\left(400 \mathrm{MHz}\right.$, DMSO- $\left.d_{6+} \mathrm{NaOD}\right): \delta=6.88-6.98$ (m, $\left.4 \mathrm{H}, \mathrm{Ar}-\mathrm{H}\right), 7.6-7.8(\mathrm{~m}, 3 \mathrm{H}, \mathrm{Ar}-$ $H), 8.1$ (s, $1 \mathrm{H},-N H$-side chain), $8.81(\mathrm{~s}, 1 \mathrm{H}, \mathrm{Ar}-H) \mathrm{ppm} ;{ }^{13} \mathrm{C}-\mathrm{NMR}\left(100 \mathrm{MHz}, \mathrm{DMSO}-d_{6}\right)$ : $\delta=100.78(2 \mathrm{C}), 102.4(2 \mathrm{C}), 123.97$ (1C), $124.04(1 \mathrm{C}), 124.31$ (1C), 124.4 (1C), 124.6(1C), 125.02 (1C), 128.9 (1C), 138.5 (1C), 141.3 (1C), 172.5 (1C), 172.91 (1C), 173.3 (1C), 176.5 (1C), ppm; IR (KBr disc): 3156, 2992, 2928, 1672, 1609, 1477, 1414, 1377, $1325 \mathrm{~cm}^{-1}$. High-resolution mass spectrum, $m / z$ : calculated 316.04889 for $\mathrm{C}_{15} \mathrm{H}_{11} \mathrm{ClN}_{3} \mathrm{O}_{3}[\mathrm{M}+\mathrm{H}]^{+}$; found 316.04878 .

\subsubsection{3. $\mathrm{N}$-(3-benzoic acid)-6-chloro-4-hydroxy-2-quinolone-3 carboxamide (18)}

A mixture of ethyl 6-chloro-4-hydroxy-2-quinolone-3-carboxylate (5) (1.00 g, $3.74 \mathrm{mmol})$ and 3-amino benzoic acid (61) $(1.50 \mathrm{~g}, 11.20 \mathrm{mmol})$ was prepared in THF $(25 \mathrm{~mL})$. A few drops of DMF were added to the solution and refluxed for $72 \mathrm{~h}$. Reaction progress was monitored by the absence of a spot of 5 on TLC and a precipitate appearance at RT. A solid residue was formed, washed with $\mathrm{H}_{2} \mathrm{O}, \mathrm{MeOH}$, and THF, and then dried in a vacuum oven at $70{ }^{\circ} \mathrm{C}$ for $1 \mathrm{~h}$.

A white powder; yield: $44.8 \%, \mathrm{R}_{f}=0.21\left(\mathrm{CHCl}_{3}\right.$ : $\left.\mathrm{MeOH}-8.0: 2.0\right)$; m.p: $342-344{ }^{\circ} \mathrm{C}$; ${ }^{1} \mathrm{H}-\mathrm{NMR}\left(400 \mathrm{MHz}\right.$, DMSO- $\left.d_{6+} \mathrm{NaOD}\right): \delta=6.96(\mathrm{~d}, J=8.4 \mathrm{~Hz}, 1 \mathrm{H}, \mathrm{Ar}-H), 7.07(\mathrm{dd}, J=2.0$, $2.4 \mathrm{~Hz}, 1 \mathrm{H}, \mathrm{Ar}-H), 7.14(\mathrm{t}, J=7.6 \mathrm{~Hz}, 1 \mathrm{H}, \mathrm{Ar}-H), 7.45(\mathrm{~d}, J=7.6 \mathrm{~Hz}, 1 \mathrm{H}, \mathrm{Ar}-H), 7.78(\mathrm{~d}$, $J=8 \mathrm{~Hz}, 1 \mathrm{H}, \mathrm{Ar}-H), 7.8(\mathrm{~s}, 1 \mathrm{H}, \mathrm{Ar}-\mathrm{H}),=8.13(\mathrm{~s}, 1 \mathrm{H}, \mathrm{Ar}-H) \mathrm{ppm} ;{ }^{13} \mathrm{C}-\mathrm{NMR}(100 \mathrm{MHz}$, DMSO- $\left.d_{6}\right): \delta=101.2(1 \mathrm{C}), 119.6(2 \mathrm{C}), 120.6(1 \mathrm{C}), 121.3(1 \mathrm{C}), 122.6(1 \mathrm{C}), 124.3(1 \mathrm{C}), 124.5$ (1C), $127.6(1 \mathrm{C}), 128.7$ (1C), $140.4(1 \mathrm{C}), 140.7$ (1C), 149.1 (1C), 169.9 (1C), 171.3(1C), 173.9(1C), 
176.0 (1C) ppm; IR (KBr disc): 3037, 2976, 2899, 1691, 1658, 1458, 1419, 1371, $1315 \mathrm{~cm}^{-1}$. High-resolution mass spectrum, $m / z$ : calculated 359.04347 for $\mathrm{C}_{17} \mathrm{H}_{12} \mathrm{ClN}_{2} \mathrm{O}_{5}[\mathrm{M}+\mathrm{H}]^{+}$; found 359.04301 .

\subsubsection{4. $\mathrm{N}$-(2-fluorphenyl)-6-chloro-4-hydroxy-2-quinolone-3-carboxamide (19)}

A mixture of ethyl 6-chloro-4-hydroxy-2-quinolone-3-carboxylate (5) $(1.00 \mathrm{~g}, 3.74 \mathrm{mmol})$ and 2-fluoroaniline $(\mathbf{6 m})(1.20 \mathrm{~g}, 11.20 \mathrm{mmol})$ was prepared in THF $(25 \mathrm{~mL})$. A few drops of DMF were added to the solution and refluxed for $72 \mathrm{~h}$. Reaction progress was monitored by the absence of a spot of 5 on TLC and a precipitate appearance at RT. A solid residue was formed, washed with $\mathrm{H}_{2} \mathrm{O}, \mathrm{MeOH}$, and THF, and then dried in a vacuum oven at $70{ }^{\circ} \mathrm{C}$ for $1 \mathrm{~h}$.

An off white powder; yield: $72.4 \%, \mathrm{R}_{f}=0.7\left(\mathrm{CHCl}_{3}: \mathrm{MeOH}-9.5: 0.5\right) ; \mathrm{m} . \mathrm{p}: 318-320{ }^{\circ} \mathrm{C}$; ${ }^{1} \mathrm{H}-\mathrm{NMR}\left(400 \mathrm{MHz}\right.$, DMSO- $\left.d_{6+} \mathrm{NaOD}\right): \delta=6.85-6.90(\mathrm{~m}, 1 \mathrm{H}, \mathrm{Ar}-H), 6.93-7.03(\mathrm{~m}, 3 \mathrm{H}, \mathrm{Ar}-\mathrm{H})$, 7.05-7.12 (m, 1H, Ar- H), $7.8(\mathrm{~s}, 1 \mathrm{H}, \mathrm{Ar}-H), 8.68(\mathrm{t}, J=8 \mathrm{~Hz}, 1 \mathrm{H}, \mathrm{Ar}-\mathrm{H}) \mathrm{ppm} ;{ }^{13} \mathrm{C}-\mathrm{NMR}$ $\left(100 \mathrm{MHz}, \mathrm{DMSO}-d_{6}\right): \delta=101.0(1 \mathrm{C}), 119.5(1 \mathrm{C}), 121.1(2 \mathrm{C}), 121.2(1 \mathrm{C}), 122.1(1 \mathrm{C}), 124.4(2 \mathrm{C})$, 124.5 (1C), 124.6 (1C), 149.5 (1C), 151.4 (1C), 153.8 (1C), 170.2 (1C), 174.0 (1C), 176.6 (1C) ppm; IR (KBr disc): 2980, 2902, 2833, 1666, 1604, 1566, 1469,1417, $1373 \mathrm{~cm}^{-1}$. High-resolution mass spectrum, $m / z$ : calculated 333.04422 for $\mathrm{C}_{16} \mathrm{H}_{11} \mathrm{ClFN}_{2} \mathrm{O}_{3}[\mathrm{M}+\mathrm{H}]^{+}$; found 333.04465 .

\subsubsection{N-(3-fluorphenyl)-6-chloro-4-hydroxy-2-quinolone-3-carboxamide (20)}

A mixture of ethyl 6-chloro-4-hydroxy-2-quinolone-3-carboxylate (5) (1.00 g, $3.74 \mathrm{mmol})$ and 3-fluoroaniline (6n) $(1.20 \mathrm{~g}, 11.20 \mathrm{mmol})$ was prepared in THF $(25 \mathrm{~mL})$. A few drops of DMF were added to the solution and refluxed for $72 \mathrm{~h}$. Reaction progress was monitored by the absence of a spot of 5 on TLC and a precipitate appearance at RT. A solid residue was formed, washed with $\mathrm{H}_{2} \mathrm{O}, \mathrm{MeOH}$, and THF, and then dried in a vacuum oven at $70{ }^{\circ} \mathrm{C}$ for $1 \mathrm{~h}$.

An off white powder; yield: $64.4 \%, \mathrm{R}_{f}=0.75\left(\mathrm{CHCl}_{3}: \mathrm{MeOH}-9.5: 0.5\right) ;$ m.p: $298-300{ }^{\circ} \mathrm{C}$; ${ }^{1} \mathrm{H}-\mathrm{NMR}\left(400 \mathrm{MHz}, \mathrm{DMSO}-d_{6+} \mathrm{NaOD}\right): \delta=6.68(\mathrm{t}, J=8.0,1 \mathrm{H}, \mathrm{Ar}-H), 7.16-7.24(\mathrm{~m}, 2 \mathrm{H}$, Ar- $H$ ), 7.80 (s, $1 \mathrm{H}, \mathrm{Ar}-H), 7.95$ (pseudo d, $1 \mathrm{H}, \mathrm{Ar}-H), 7.97(\mathrm{~d}, J=8.8 \mathrm{~Hz}, 1 \mathrm{H}, \mathrm{Ar}-\mathrm{H}) \mathrm{ppm}$; ${ }^{13} \mathrm{C}-\mathrm{NMR}\left(100 \mathrm{MHz}, \mathrm{DMSO}-d_{6}\right): \delta=100.95$ (1C), 106.5 (1C), 107.3 (1C), 115.3 (1C), 119.9 (1C), 124.3 (2C), 128.9 (1C), 130.1 (1C), 130.2 (1C), 143.5 (1C), 149.2 (1C), 161.7 (1C), 164.1 (1C), 170.1 (1C), 173.5 (1C), 176.4 (1C) ppm; IR (KBr disc): 2972, 2899, 2829, 1658, 1604, 1493, $1415,1554,1373,1328 \mathrm{~cm}^{-1}$. High-resolution mass spectrum, $m / z$ : calculated 333.04422 for $\mathrm{C}_{16} \mathrm{H}_{11} \mathrm{ClFN}_{2} \mathrm{O}_{3}[\mathrm{M}+\mathrm{H}]^{+}$; found 333.04411.

\subsubsection{6. $\mathrm{N}$-(4-fluorphenyl)-6-chloro-4-hydroxy-2-quinolone-3-carboxamide (21)}

A mixture of ethyl 6-chloro-4-hydroxy-2-quinolone-3-carboxylate (5) $(1.00 \mathrm{~g}, 3.74 \mathrm{mmol})$ and 4-fluoroaniline (6o) $(1.20 \mathrm{~g}, 11.20 \mathrm{mmol})$ was prepared in THF $(25 \mathrm{~mL})$. A few drops of DMF were added to the solution and refluxed for $72 \mathrm{~h}$. Reaction progress was monitored by the absence of a spot of $\mathbf{5}$ on TLC and a precipitate appearance at RT. A solid residue was formed, washed with $\mathrm{H}_{2} \mathrm{O}, \mathrm{MeOH}$, and THF, and then dried in a vacuum oven at $70{ }^{\circ} \mathrm{C}$ for $1 \mathrm{~h}$.

An off white powder; yield: $80.5 \%, \mathrm{R}_{f}=0.75\left(\mathrm{CHCl}_{3}: \mathrm{MeOH}-9.5: 0.5\right)$; m.p: $300-302{ }^{\circ} \mathrm{C}$; ${ }^{1} \mathrm{H}-\mathrm{NMR}\left(400 \mathrm{MHz}\right.$, DMSO- $\left.d_{6+} \mathrm{NaOD}\right): \delta=6.95-7.03(\mathrm{~m}, 3 \mathrm{H}, \mathrm{Ar}-H), 7.06(\mathrm{dd}, J=2.4,2.4 \mathrm{~Hz}$, $1 \mathrm{H}, \mathrm{Ar}-H), 7.68-7.71(\mathrm{~m}, 2 \mathrm{H}, \mathrm{Ar}-\mathrm{H}), 7.81(\mathrm{~d}, J=2.8 \mathrm{~Hz}, 1 \mathrm{H}, \mathrm{Ar}-\mathrm{H}) \mathrm{ppm} ;{ }^{13} \mathrm{C}-\mathrm{NMR}(100 \mathrm{MHz}$, DMSO- $\left.d_{6}\right): \delta=101.1(1 \mathrm{C}), 115.1(2 \mathrm{C}), 119.9(1 \mathrm{C}), 121.2(2 \mathrm{C}), 121.3(2 \mathrm{C}), 124.2(1 \mathrm{C}), 138.0$ (1C), 149.0 (1C), 156.1 (1C), 158.4 (1C), 169.8 (1C), 173.6 (1C), 176.1 (1C) ppm; IR (KBr disc): $3045,2972,2902,1662,1614,1506,1467,1415,1371 \mathrm{~cm}^{-1}$. High-resolution mass spectrum, $\mathrm{m} / \mathrm{z}$ : calculated 333.04422 for $\mathrm{C}_{16} \mathrm{H}_{11} \mathrm{ClFN}_{2} \mathrm{O}_{3}[\mathrm{M}+\mathrm{H}]^{+}$; found 333.04479 .

\subsubsection{N-(6-methylbenzoic acid)-6-chloro-4-hydroxy-2-quinolone-3-carboxamide (22)}

A mixture of ethyl 6-chloro-4-hydroxy-2-quinolone-3-carboxylate (5) $(1.00 \mathrm{~g}, 3.74 \mathrm{mmol})$ and 2-amino-6-methyl benzoic acid $(6 \mathbf{p})(1.70 \mathrm{~g}, 11.20 \mathrm{mmol})$ was prepared in THF $(25 \mathrm{~mL})$. A few drops of DMF were added to the solution and refluxed for $72 \mathrm{~h}$. Reaction progress 
was monitored by the absence of a spot of $\mathbf{5}$ on TLC and a precipitate appearance at RT. A solid residue was formed, washed with $\mathrm{H}_{2} \mathrm{O}, \mathrm{MeOH}$, and THF, and then dried in a vacuum oven at $70{ }^{\circ} \mathrm{C}$ for $1 \mathrm{~h}$.

An off white powder; yield: 79\%, $\mathrm{R}_{f}=0.56\left(\mathrm{CHCl}_{3}\right.$ : $\left.\mathrm{MeOH}-9.5: 0.5\right) ;$ m.p: $284-285{ }^{\circ} \mathrm{C}$; ${ }^{1} \mathrm{H}-\mathrm{NMR}\left(400 \mathrm{MHz}, \mathrm{DMSO}-d_{6+} \mathrm{NaOD}\right): \delta=2.23\left(\mathrm{~s}, 1 \mathrm{H},-\mathrm{CH}_{3}\right), 6.67(\mathrm{~d}, J=7.2 \mathrm{~Hz}, 1 \mathrm{H}, \mathrm{Ar}-\mathrm{H})$, $6.89(\mathrm{t}, J=8 \mathrm{~Hz}, 1 \mathrm{H}, \mathrm{Ar}-H), 6.99(\mathrm{~d}, J=8.8 \mathrm{~Hz}, 1 \mathrm{H}, \mathrm{Ar}-H), 7.05(\mathrm{~d}, J=7.2 \mathrm{~Hz}, 1 \mathrm{H}, \mathrm{Ar}-H)$, $7.89(\mathrm{~s}, 1 \mathrm{H}, \mathrm{Ar}-H), 8.23(\mathrm{~d}, J=8 \mathrm{~Hz}, 1 \mathrm{H}, \mathrm{Ar}-H) \mathrm{ppm} ;{ }^{13} \mathrm{C}-\mathrm{NMR}\left(100 \mathrm{MHz}, \mathrm{DMSO}-d_{6}\right)$ : $\delta=20.3(1 \mathrm{C}), 101.8(1 \mathrm{C}), 119.1$ (1C), 120.03 (1C), 122.7 (1C), 124.5 (1C), 124.7 (1C), 125.03 (1C), 125.4 (2C), 132.0 (1C), 135.7 (1C), 136.2 (1C)), 148.9 (1C), $169.8(1 C), 173.9(1 C), 174.7$ (1C),175.8 (1C) ppm; IR (KBr disc): 3482, 3127, 2965, 1680, 1612, 1549, 1470, 1418, $1377 \mathrm{~cm}^{-1}$. High-resolution mass spectrum, $m / z$ : calculated 373.05912 for $\mathrm{C}_{18} \mathrm{H}_{14} \mathrm{ClN}_{2} \mathrm{O}_{5}[\mathrm{M}+\mathrm{H}]^{+}$; found 373.05945 .

3.2.18. N-(5-methylbenzoic acid)-6-chloro-4-hydroxy-2-quinolone-3-carboxamide (23)

A mixture of ethyl 6-chloro-4-hydroxy-2-quinolone-3-carboxylate (5) (1.00 g, $3.74 \mathrm{mmol})$ and 2-amino-5-methyl benzoic acid (6q) $(1.70 \mathrm{~g}, 11.20 \mathrm{mmol})$ was prepared in THF (25 $\mathrm{mL})$. A few drops of DMF were added to the solution and refluxed for $72 \mathrm{~h}$. Reaction progress was monitored by the absence of a spot of 5 on TLC and a precipitate appearance at RT. A solid residue was formed, washed with $\mathrm{H}_{2} \mathrm{O}, \mathrm{MeOH}$, and THF, and then dried in a vacuum oven at $70{ }^{\circ} \mathrm{C}$ for $1 \mathrm{~h}$.

An off white powder; yield: $71.8 \%, \mathrm{R}_{f}=0.26\left(\mathrm{CHCl}_{3}: \mathrm{MeOH}-8.0: 2.0\right)$; m.p: $318-320{ }^{\circ} \mathrm{C}$; ${ }^{1} \mathrm{H}-\mathrm{NMR}\left(400 \mathrm{MHz}, \mathrm{DMSO}-d_{6+} \mathrm{NaOD}\right): \delta=2.22\left(\mathrm{~s}, 3 \mathrm{H}, \mathrm{CH}_{3}\right), 6.91-6.93(\mathrm{~m}, 2 \mathrm{H}, \mathrm{Ar}-\mathrm{H}), 6.99-7$. 01 (m, 1H, Ar-H), 7.53 (s, 1H, Ar-H), 7.90 (s, 1H, Ar-H), 8.50 (d, J=8 Hz, 1H, Ar-H) ppm; ${ }^{13} \mathrm{C}-\mathrm{NMR}\left(100 \mathrm{MHz}, \mathrm{DMSO}-d_{6}\right): \delta=20.9$ (1C), $102.6(1 \mathrm{C}), 119.4(2 \mathrm{C}), 122.2(1 \mathrm{C}), 124.5(1 \mathrm{C})$, 124.6 (1C), 128.3 (2C), 128.4 (1C), 125.5 (2C), 129.8 (1C), $149.4(1 \mathrm{C}), 170.1(1 \mathrm{C})), 172.9(1 \mathrm{C}))$, 174.1 (1C)), 175.6 (1C) ppm; IR (KBr disc): 3128, 2949, 2891, 1658, 1616, 1579, 1529, 1460, $1436 \mathrm{~cm}^{-1}$. High-resolution mass spectrum, $m / z$ : calculated 373.05912 for $\mathrm{C}_{18} \mathrm{H}_{14} \mathrm{ClN}_{2} \mathrm{O}_{5}$ $[\mathrm{M}+\mathrm{H}]^{+}$; found 373.05978 .

\subsubsection{N-(4-methoxybenzoic acid)-6-chloro-4-hydroxy-2-quinolone-3-carboxamide (24)}

A mixture of ethyl 6-chloro-4-hydroxy-2-quinolone-3-carboxylate (5) (1.00 g, $3.74 \mathrm{mmol})$ and 2-amino-4-methoxy benzoic acid (6r) (1.90 g, $11.20 \mathrm{mmol})$ was prepared in THF (25 $\mathrm{mL})$. A few drops of DMF were added to the solution and refluxed for $72 \mathrm{~h}$. Reaction progress was monitored by the absence of a spot of 5 on TLC and a precipitate appearance at RT. A solid residue was formed, washed with $\mathrm{H}_{2} \mathrm{O}, \mathrm{MeOH}$, and $\mathrm{THF}$, and then dried in a vacuum oven at $70{ }^{\circ} \mathrm{C}$ for $1 \mathrm{~h}$.

A white powder; yield: $82.6 \%, \mathrm{R}_{f}=0.13\left(\mathrm{CHCl}_{3}\right.$ : $\left.\mathrm{MeOH}-8.0: 2.0\right)$; m.p: $273-274{ }^{\circ} \mathrm{C}$; ${ }^{1} \mathrm{H}-\mathrm{NMR}\left(400 \mathrm{MHz}, \mathrm{DMSO}-d_{6+} \mathrm{NaOD}\right): \delta=3.73\left(\mathrm{~s}, 3 \mathrm{H}, \mathrm{CH}_{3}\right), 6.37(\mathrm{dd}, \mathrm{J}=2.4,2.4 \mathrm{~Hz}$, $1 \mathrm{H}, \mathrm{Ar}-H), 6.92(\mathrm{~d}, J=8.8 \mathrm{~Hz}, 1 \mathrm{H}, \mathrm{Ar}-H), 7.01-7.03(\mathrm{~m}, 1 \mathrm{H}, \mathrm{Ar}-H), 7.69(\mathrm{~d}, J=8.4 \mathrm{~Hz}, 1 \mathrm{H}$, Ar- $H), 7.87(\mathrm{~d}, J=4 \mathrm{~Hz}, 1 \mathrm{H}, \mathrm{Ar}-H), 8.39$ (s, $1 \mathrm{H}, \mathrm{Ar}-H)$ ppm; ${ }^{13} \mathrm{C}-\mathrm{NMR}\left(100 \mathrm{MHz}, \mathrm{DMSO}-d_{6}\right)$ : $\delta=55.26(1 \mathrm{C}), 103.2(1 \mathrm{C}), 105.7(1 \mathrm{C}), 106.7$ (2C), $119.5(1 \mathrm{C}), 121.7(2 \mathrm{C}), 124.3(1 \mathrm{C}), 124.5(1 \mathrm{C})$, $125.3(1 \mathrm{C}), 131.9(1 \mathrm{C}), 142.0(1 \mathrm{C}), 149.2(1 \mathrm{C}), 159.9$ (1C), $170.5(1 \mathrm{C}), 172.2(1 \mathrm{C}), 173.5(1 \mathrm{C})$, 175.2(1C) ppm; IR (KBr disc): 3124, 2920, 2845, 1676, 1616, 1544, 1446, 1377, $1261 \mathrm{~cm}^{-1}$. High-resolution mass spectrum, $m / z$ : calculated 389.05404 for $\mathrm{C}_{18} \mathrm{H}_{14} \mathrm{ClN}_{2} \mathrm{O}_{6}[\mathrm{M}+\mathrm{H}]^{+}$; found 389.05425 .

\subsection{Biology \\ 3.3.1. Culture Conditions}

Two human colon cancer cell lines-Caco-2 and HCT-116-were grown in DMEM culture medium (Dulbecco's modified essential medium, Gibco), complemented with 5\% $(v / v)$ fetal calf serum (JS Bioscience, Melbourne, Australia), and 1\% (v/v) antibiotic (2 mM Lglutamine, $100 \mathrm{U} / \mathrm{mL}$ Penicillin and $0.1 \mathrm{mg} / \mathrm{mL}$ Streptomycin; Gibco). Cells were cultured at $37{ }^{\circ} \mathrm{C}$ in a humidified $5 \% \mathrm{CO}_{2}$ incubator. Enzymatic detachment of the confluent cell layers was carried out using Trypsin/EDTA (Gibco, Gaithersburg, MD, USA). To assess cell 
viability, trypan blue vital staining $(0.4 \%(w / v)$; Sigma, New York, NY, USA) was employed with cell number, which was evaluated using a light microscope.

\subsubsection{MTT Assay}

All cells were plated at a density of $8 \times 10^{3}$ cells per well in 96-well plates and incubated to allow attachment for $24 \mathrm{~h}$. The in vitro evaluation of the antiproliferative activities of the examined series was accomplished using the 3-(4,5-dimethylthiazol-2yl)2,5-diphenyl tetrazolium bromide (MTT) colorimetric assay, as previously described [42]. In short, compounds were diluted in culture media to yield the required concentration and applied to test wells for $48 \mathrm{~h}$ at $37^{\circ} \mathrm{C}$ in a $5 \% \mathrm{CO}_{2}$ incubator. Three triplicates of each concentration for all tested compounds were conducted in three independent assays $(n=9)$. DMEM samples were employed as negative controls, and LY294002 as a positive control. At the end of the exposure period, $20 \mu \mathrm{L}$ of $0.5 \mathrm{mg} / \mathrm{mL}$ of MTT was added to each well and incubated for $4 \mathrm{~h}$, afterword its reduction to formazan by metabolically active cells was calculated via measuring the absorbance at $570 \mathrm{~nm}$. Cell viability was calculated based on the measured absorbance relative to the absorbance of the cells exposed to the negative control, which represented $100 \%$ cell viability.

\subsubsection{Statistical Analysis}

Data analysis was performed using GraphPad Prism software version 7. The differences between treatments groups were determined by t-test or one-way analysis of variance (ANOVA) followed by Tukey post hoc t-test as appropriate. Data were expressed as mean $\pm \mathrm{SD}$ and $p<0.05$ was considered a statistically significant difference. A non-linear regression analysis was used to calculate $\mathrm{IC}_{50}$ values.

\subsubsection{Quantitative Real-Time PCR \\ RNA Extraction}

Total RNA was extracted from the cultured cells using Quick-RNA MiniPrep according to the manufacturer's instructions as follows: harvested cells were re-suspended in RNA lysis buffer and centrifuged, the supernatant then was transferred into a Spin-Away Filter in a collection tube and centrifuged, and then $95 \%$ ethanol was added and mixed well. The mixture was then transferred to a Zymo-Spin IIICG Column in a collection tube and centrifuged, followed by adding RNA Prep Buffer to the column, followed by two washing steps by adding RNA wash buffer to the column and then centrifugation. Finally, the RNA was eluted by adding DNase/RNase-free water to the column and centrifuged. Samples were quantified using a spectrophotometer via absorbance at $260 / 280 \mathrm{~nm}$.

\section{Complementary DNA (cDNA) Synthesis}

Complementary cDNA synthesis was performed using a ProtoScript First Strand cDNA Synthesis Kit following the manufacturer's instructions. In brief, 1000 nanogram from total RNA was add to a total $20 \mu \mathrm{L}$ reaction volume that included $60 \mu \mathrm{M}$ random primer mix, reaction mix, $10 \times$ enzyme mix, and nuclease-free water. The tubes were then incubated at $25^{\circ} \mathrm{C}$ for $5 \mathrm{~min}$ followed by incubation at $42{ }^{\circ} \mathrm{C}$ for $1 \mathrm{~h}$. The cDNA was then then stored at $-20^{\circ} \mathrm{C}$ until further analysis.

\section{Real-Time PCR}

The sequences of the primers that were used in real-time PCR assay are shown in Table 4. The reaction mixtures consisted of $200 \mathrm{ng}$ cDNA template, $10 \mu \mathrm{M}$ of each primer, $10 \mu \mathrm{L}$ of $2 X$ SYBER Premix Ex Taq II (Takara BIO INC, Shiga, Japan), and the total reaction volume was $20 \mu \mathrm{L}$. The reaction was carried out using a BIO RAD iQ5 Multicolor real-time PCR Detection System thermal cycler under the following reaction conditions: 1 cycle of $2 \mathrm{~min}$ at $95.0^{\circ} \mathrm{C}$, followed by 45 cycles of $10 \mathrm{~s}$ at $95.0^{\circ} \mathrm{C}, 25 \mathrm{~s}$ at $57.0^{\circ} \mathrm{C}, 25 \mathrm{~s}$ at $60.0^{\circ} \mathrm{C}$, and a final cycle of $30 \mathrm{~s}$ at $55.0^{\circ} \mathrm{C}$. To confirm that only one PCR product was amplified, 
dissociation curve analysis of amplification products was performed at the end of the last amplification cycle.

Table 4. Sequences of primers that were used to detect the expression of $\beta$-actin, BAD, PI3K, and AKT.

\begin{tabular}{ccc}
\hline Target & $\begin{array}{c}\text { Forward Primers } \\
\left(\mathbf{5}^{\prime} \rightarrow \mathbf{3}^{\prime} \mathbf{)}\right.\end{array}$ & $\begin{array}{c}\text { Reverse Primers } \\
\left(\mathbf{5}^{\prime} \rightarrow \mathbf{3}^{\prime} \mathbf{)}\right.\end{array}$ \\
\hline$\beta$-actin & ACGGGGTCACCCACACTGTGC & CTAGAAGCATTTGCGGTGGACGATG \\
\hline BAD & CCTCAGGCCTATGCAAAAAG & AAACCCAAAACTTCCGATGG \\
\hline PI3K & ACCCAGCAACAGAAAAATGG & GCGCTGTGAATTTAGCCTTC \\
\hline AKT & AACCTGTGCTCCATGACCTC & CCCTTCTACAACCAGGACCA \\
\hline
\end{tabular}

\subsection{Computational Methods}

\subsubsection{Preparation of PI3K $\alpha$ Structure}

The co-ordinates of WT PI3K $\alpha$ s (PDB ID: 2RD0) [9] and (PDB ID: 4L23) [39] as well as MUT (H1047R) PI3K $\alpha$ (PDB ID: 3HHM) [35] were obtained from the RCSB Protein Data Bank [3-45]. The template of X6K in 4L23 [39] was conveyed to 2RD0 and pinpointed as a ligand to extract the grid file. The homology modeled assemblies of 2RD0 and 3HHM were previously reported by our research group [19] and employed for this study. The co-ordinates of 2RD0 and 3HHM were energetically minimized to avoid steric clash. Extra treatment for the minimized co-ordinates was executed using Protein Preparation algorithm in Schrödinger software [38] to maximize H-bond interactions between side chains.

\subsubsection{Preparation of Ligand Structures}

The verified compounds (ligands) were modeled using wortmannin's template in 3HHM. The ligands were built by MAESTRO [38] Build script and energetically minimized by the MacroModel algorithm using OPLS2005 force field.

\subsubsection{Induced-Fit Docking (IFD)}

The adopted ligand (wortmannin) was labeled as a centroid in 2RD0 [9] and 3HMM [35] kinase domains. The Van der Waals scaling factors for receptor and ligand were calibrated to 0.5 to provide adequate flexibility for the best docked ligand pose. Other parameters were adjusted as default. The ligand geometry with the highest XP Glide binding affinity was recorded.

\subsubsection{Molecular Descriptors}

All molecular structures, sketched in ChemDraw [46] and saved in SDF file format, were standardized according to the methods described by Hajjo et al. [47]. Next, two groups of molecular descriptors, comprising 'Drug-like Indices' and 'Molecular Properties' calculated using alvaDesc software from Kode Cheminformatics [48], were generated for compounds, 5,7-27.

\subsubsection{Principal Component Analysis (PCA)}

A principal component analysis was performed on structures $\mathbf{5}$ and 7-27 using druglike indices and molecular properties. All calculations and PCA analysis were performed using alvaDesc software from Kode Cheminformatics [48].

\section{Conclusions}

The phosphatidylinositol 3-kinase $(\mathrm{PI} 3 \mathrm{~K} \alpha)$ has been recognized as a "hot" target for anticancer drug design. We disclosed a library of N-phenyl-6-chloro-4-hydroxy-2quinolone-3-carboxamides as potential $\mathrm{PI} 3 \mathrm{~K} \alpha$ inhibitors.

Biological investigation in Caco-2 and HCT116 cell lines showed potent suppression HCT-116 mediated by compounds $(\mathbf{1 6}, \mathbf{1 8}, \mathbf{1 9}, \mathbf{2 1}$, and 24). IFD studies against PI3K $\alpha$ s 
illustrated that the series accommodate PI3K $\alpha$ s binding sites and engage with key residues involved in inhibitor interactions. We are looking for optimizing the core structure of this series to induce its anticancer activity and selectivity against a panel of kinases.

Supplementary Materials: The following are available online: Table S1: Calculated descriptors of the synthesized compounds (5, 7-24).

Author Contributions: D.A.S. managed study design, hypothesis, synthesis protocols, modeling studies, and writing the manuscript. R.A.H. performed synthesis reaction and purification of prospective molecules. S.K.B. conducted cancer biology investigations and transcribed biological results and discussion. R.H. accomplished molecular descriptor analysis and delineated cheminformatics results and discussion. K.S. interpreted NMR spectra and HRMS results and revised chemistry part. All authors have read and agreed to the published version of the manuscript.

Funding: This work was financially sponsored by the Scientific Research Support Fund of the Ministry of Higher Education \& Scientific Research and the Deanship of Scientific Research and Graduate Studies at Al-Zaytoonah University of Jordan (Grant number: MPH/1/8/2017).

Acknowledgments: We acknowledge the University of Jordan and Hashemite University, the Chemistry Departments, for spectroscopic facilities. We thank the College of Pharmacy, the University of Jordan, for offering cell culture laboratory and equipment.

Conflicts of Interest: The authors declare no conflict of interest.

Sample Availability: Samples of the compounds are available from the authors.

\section{References}

1. Bray, F.; Ferlay, J.; Soerjomataram, I.; Siegel, R.L.; Torre, L.A.; Jemal, A. Global cancer statistics 2018: GLOBOCAN estimates of incidence and mortality worldwide for 36 cancers in 185 countries. CA Cancer J. Clin. 2018, 68, 394-424. [CrossRef] [PubMed]

2. Ames, B.N.; Gold, L.S.; Willett, W.C. The causes and prevention of cancer. Proc. Natl. Acad. Sci. USA 1995, 92, 5258-5265. [CrossRef] [PubMed]

3. Hussain, S.P.; Hofseth, L.J.; Harris, C.C. Radical causes of cancer. Nat. Rev. Cancer 2003, 3, 276-285. [CrossRef]

4. Wagner, L.I.; Cella, D. Fatigue and cancer: Causes, prevalence and treatment approaches. Br. J. Cancer 2004, 91, 822-828. [CrossRef] [PubMed]

5. Marks, P.A.; Rifkind, R.A.; Richon, V.M.; Breslow, R.; Miller, T.; Kelly, W.K. Histone deacetylases and cancer: Causes and therapies. Nat. Rev. Cancer 2001, 1, 194-202. [CrossRef] [PubMed]

6. Vanhaesebroeck, B.; Waterfield, M.D. Signaling by Distinct Classes of Phosphoinositide 3-Kinases. Exp. Cell Res. 1999, 253, 239-254. [CrossRef]

7. Vanhaesebroeck, B.; Guillermet-Guibert, J.; Graupera, M.; Bilanges, B. The emerging mechanisms of isoform-specific PI3K signalling. Nat. Rev. Mol. Cell Biol. 2010, 11, 329-341. [CrossRef]

8. Cantley, L.C. The Phosphoinositide 3-Kinase Pathway. Science 2002, 296, 1655-1657. [CrossRef]

9. Huang, C.-H.; Mandelker, D.; Schmidt-Kittler, O.; Samuels, Y.; Velculescu, V.E.; Kinzler, K.W.; Vogelstein, B.; Gabelli, S.B.; Amzel, L.M. The Structure of a Human p110 /p85 Complex Elucidates the Effects of Oncogenic PI3K Mutations. Science 2007, 318, 1744-1748. [CrossRef]

10. Vivanco, I.; Sawyers, C.L. The phosphatidylinositol 3-Kinase-AKT pathway in human cancer. Nat. Rev. Cancer 2002, 2, 489-501. [CrossRef]

11. Samuels, Y.; Wang, Z.; Bardelli, A.; Silliman, N.; Ptak, J.; Szabo, S.; Yan, H.; Gazdar, A.; Powell, S.M.; Riggins, G.J.; et al. High Frequency of Mutations of the PIK3CA Gene in Human Cancers. Science 2004, 304, 554. [CrossRef] [PubMed]

12. Samuels, Y.; Diaz, L.A.; Schmidt-Kittler, O.; Cummins, J.M.; Delong, L.; Cheong, I.; Rago, C.; Huso, D.L.; Lengauer, C.; Kinzler, K.W.; et al. Mutant PIK3CA promotes cell growth and invasion of human cancer cells. Cancer Cell 2005, 7, 561-573. [CrossRef] [PubMed]

13. Zhao, L.; Vogt, P.K. Helical domain and kinase domain mutations in p110 of phosphatidylinositol 3-kinase induce gain of function by different mechanisms. Proc. Natl. Acad. Sci. USA 2008, 105, 2652-2657. [CrossRef] [PubMed]

14. Liu, P.; Cheng, H.; Roberts, T.M.; Zhao, J.J. Targeting the phosphoinositide 3-kinase pathway in cancer. Nat. Rev. Drug Discov. 2009, 8, 627-644. [CrossRef] [PubMed]

15. Cully, M.; You, H.; Levine, A.J.; Mak, T.W. Beyond PTEN mutations: The PI3K pathway as an integrator of multiple inputs during tumorigenesis. Nat. Rev. Cancer 2006, 6, 184-192. [CrossRef] [PubMed]

16. Carracedo, A.; Pandolfi, P.P. The PTEN-PI3K pathway: Of feedbacks and cross-talks. Oncogene 2008, 27, 5527-5541. [CrossRef]

17. NCI Open Database Compounds Release 3; National Cancer Institute: Bethseda, MD, USA, 2013. Available online: http://cactus.nci. nih.gov/download/nci (accessed on 15 October 2020). 
18. Sabbah, D.A.; Simms, N.A.; Brattain, M.G.; Vennerstrom, J.L.; Zhong, H. Biological evaluation and docking studies of recently identified inhibitors of phosphoinositide-3-kinases. Bioorg. Med. Chem. Lett. 2012, 22, 876-880. [CrossRef] [PubMed]

19. Sabbah, D.A.; Vennerstrom, J.L.; Zhong, H.A. Docking Studies on Isoform-Specific Inhibition of Phosphoinositide-3-Kinases. J. Chem. Inf. Model. 2010, 50, 1887-1898. [CrossRef]

20. MOE. Version 2016; The Molecular Operating, Environment Chemical Computing Group, Inc.: Montreal, QC, Canada, 2016.

21. Sabbah, D.A.; Vennerstrom, J.L.; Zhong, H.A. Binding Selectivity Studies of Phosphoinositide 3-Kinases Using Free Energy Calculations. J. Chem. Inf. Model. 2012, 52, 3213-3224. [CrossRef]

22. Sabbah, D.A.; Simms, N.A.; Wang, W.; Dong, Y.; Ezell, E.L.; Brattain, M.G.; Vennerstrom, J.L.; Zhong, H.A. N-Phenyl-4-hydroxy-2quinolone-3-carboxamides as selective inhibitors of mutant H1047R phosphoinositide-3-kinase (PI3K $\alpha$ ). Bioorg. Med. Chem. 2012, 20, 7175-7183. [CrossRef]

23. Sabbah, D.A.; Hishmah, B.; Sweidan, K.A.; Bardaweel, S.; AlDamen, M.; Zhong, H.A.; Abu Khalaf, R.; Ibrahim, A.H.; Al-Qirim, T.; Abu Sheikha, G.; et al. Structure-Based Design: Synthesis, X-ray Crystallography, and Biological Evaluation of N-Substituted4-Hydroxy-2-Quinolone-3-Carboxamides as Potential Cytotoxic Agents. Anti-Cancer Agents Med. Chem. 2018, 18, $263-276$. [CrossRef] [PubMed]

24. Sabbah, D.A.; Saada, M.; Abu Khalaf, R.; Bardaweel, S.; Sweidan, K.; Al-Qirim, T.; Al-Zughier, A.; Halim, H.A.; Abu Sheikha, G. Molecular modeling based approach, synthesis, and cytotoxic activity of novel benzoin derivatives targeting phosphoinostide 3-kinase (PI3K $\alpha)$. Bioorg. Med. Chem. Lett. 2015, 25, 3120-3124. [CrossRef] [PubMed]

25. Sweidan, K.A.; Sabbah, D.A.; Bardaweel, S.; Abu Dush, K.; Abu Sheikha, G.; Mubarak, M.S. Computer-aided design, synthesis, and biological evaluation of new indole-2-carboxamide derivatives as PI3K $\alpha$ /EGFR inhibitors. Bioorg. Med. Chem. Lett. 2016, 26, 2685-2690. [CrossRef] [PubMed]

26. Sweidan, K.; Sabbah, D.A.; Bardaweel, S.; Abu Sheikha, G.; Al-Qirim, T.; Salih, H.; El-Abadelah, M.M.; Mubarak, M.S.; Voelter, W. Facile synthesis, characterization, and cytotoxicity study of new 3-(indol-2-yl)bicyclotetrazatridecahexaens. Can. J. Chem. 2017, 95, 858-862. [CrossRef]

27. Sweidan, K.; Zalloum, H.; Sabbah, D.A.; Idris, G.; Abudosh, K.; Mubarak, M.S. Synthesis, characterization, and anticancer evaluation of some new N1-(anthraquinon-2-yl) amidrazone derivatives. Can. J. Chem. 2018, 96, 1123-1128. [CrossRef]

28. Sabbah, D.A.; Al-Tarawneh, F.; Talib, W.H.; Sweidan, K.A.; Bardaweel, S.K.; Al-Shalabi, E.; Zhong, H.A.; Abu Sheikha, G.; Abu Khalaf, R.; Mubarak, M.S. Benzoin Schiff Bases: Design, Synthesis, and Biological Evaluation as Potential Antitumor Agents. Med. Chem. 2018, 14, 695-708. [CrossRef]

29. Sabbah, D.A.; Ibrahim, A.H.; Talib, W.H.; Alqaisi, K.M.; Sweidan, K.; Bardaweel, S.K.; Sheikha, G.A.; Zhong, H.A.; Al-Shalabi, E.; Khalaf, R.A.; et al. Ligand-Based Drug Design: Synthesis and Biological Evaluation of Substituted Benzoin Derivatives as Potential Antitumor Agents. Med. Chem. 2019, 15, 417-429. [CrossRef]

30. Sabbah, D.A.; Hasan, S.E.; Abu Khalaf, R.; Bardaweel, S.K.; Hajjo, R.; Alqaisi, K.M.; Sweidan, K.A.; Al-Zuheiri, A.M. Molecular Modeling, Synthesis and Biological Evaluation of N-Phenyl-4-Hydroxy-6-Methyl-2-Quinolone-3-CarboxAmides as Anticancer Agents. Molecules 2020, 25, 5348. [CrossRef]

31. Wang, Q.; Wang, X.; Hernandez, A.; Kim, S.; Evers, B.M. Inhibition of the phosphatidylinositol 3-kinase pathway contributes to HT29 and Caco-2 intestinal cell differentiation. Gastroenterology 2001, 120, 1381-1392. [CrossRef]

32. Sambuy, Y.; De Angelis, I.; Ranaldi, G.; Scarino, M.L.; Stammati, A.; Zucco, F. The Caco-2 cell line as a model of the intestinal barrier: Influence of cell and culture-related factors on Caco-2 cell functional characteristics. Cell Biol. Toxicol. 2005, 21, 1-26. [CrossRef]

33. Sheng, H.; Shao, J.; Townsend, C.M.; Evers, B.M. Phosphatidylinositol 3-kinase mediates proliferative signals in intestinal epithelial cells. Gut 2003, 52, 1472-1478. [CrossRef] [PubMed]

34. Brattain, M.G.; Levine, A.E.; Chakrabarty, S.; Yeoman, L.C.; Willson, J.K.V.; Long, B. Heterogeneity of human colon carcinoma. Cancer Metastasis Rev. 1984, 3, 177-191. [CrossRef] [PubMed]

35. Mandelker, D.; Gabelli, S.B.; Schmidt-Kittler, O.; Zhu, J.; Cheong, I.; Huang, C.-H.; Kinzler, K.W.; Vogelstein, B.; Amzel, L.M. A frequent kinase domain mutation that changes the interaction between PI3K and the membrane. Proc. Natl. Acad. Sci. USA 2009, 106, 16996-17001. [CrossRef] [PubMed]

36. Friesner, R.A.; Banks, J.L.; Murphy, R.B.; Halgren, T.A.; Klicic, J.J.; Mainz, D.T.; Repasky, M.P.; Knoll, E.H.; Shelley, M.; Perry, J.K.; et al. Glide: A New Approach for Rapid, Accurate Docking and Scoring. 1. Method and Assessment of Docking Accuracy. J. Med. Chem. 2004, 47, 1739-1749. [CrossRef] [PubMed]

37. Friesner, R.A.; Murphy, R.B.; Repasky, M.P.; Frye, L.L.; Greenwood, J.R.; Halgren, T.A.; Sanschagrin, P.C.; Mainz, D.T. Extra Precision Glide: Docking and Scoring Incorporating a Model of Hydrophobic Enclosure for Protein-Ligand Complexes. J. Med. Chem. 2006, 49, 6177-6196. [CrossRef]

38. Schrödinger, R. Protein Preparation Wizard, Maestro, Macromodel, QPLD-Dock, and Pymol; Schrödinger, LLC: Portland, OR, USA, 2016; p. 97204.

39. Zhao, Y.; Zhang, X.; Chen, Y.; Lu, S.; Peng, Y.; Wang, X.; Guo, C.; Zhou, A.; Zhang, J.; Luo, Y.; et al. Crystal structures of PI3Kalpha complexed with PI103 and Its derivatives: New directions for inhibitors design. ACS Med. Chem. Lett. 2013, 5, 138-142. [CrossRef] [PubMed]

40. Sweidan, K.A.; Sabbah, D.A.; Engelmann, J.; Abdel-Halim, H.; Abu Sheikha, G. Computational Docking Studies of Novel Heterocyclic Carboxamides as Potential PI3K $\alpha$ Inhibitors. Lett. Drug Des. Discov. 2015, 12, 856-863. [CrossRef] 
41. alvaDesc. Available online: https://chm.kode-solutions.net/products_alvadesc.php (accessed on 15 October 2020).

42. Bardaweel, S.K.; Abu-Dahab, R.; Almomani, N.F. An in vitro based investigation into the cytotoxic effects of D-amino acids. Acta Pharm. 2013, 63, 467-478. [CrossRef]

43. Berman, H.M.; Henrick, K.; Nakamura, H. Announcing the worldwide Protein Data Bank. Nat. Struct. Mol. Biol. 2003, 10, 980. [CrossRef]

44. Berman, H.M.; Henrick, K.; Nakamura, H.; Markley, J.L. The worldwide Protein Data Bank (wwPDB): Ensuring a single, uniform archive of PDB data. Nucleic Acids Res. 2007, 35, D301-D303. [CrossRef]

45. Burley, S.K.; Berman, H.M.; Bhikadiya, C.; Bi, C.; Chen, L.; Di Costanzo, L.; Christie, C.; Duarte, J.M.; Dutta, S. Protein Data Bank: The single global archive for 3D macromolecular structure data. Nucleic Acids Res. 2019, 47, D520-D528. [CrossRef]

46. Mendelsohn, L.D. ChemDraw 8 Ultra, Windows and Macintosh Versions. J. Chem. Inf. Comput. Sci. 2004, 44, 2225-2226. [CrossRef]

47. Hajjo, R.; Setola, V.; Roth, B.L.; Tropsha, A. Chemocentric Informatics Approach to Drug Discovery: Identification and Experimental Validation of Selective Estrogen Receptor Modulators as Ligands of 5-Hydroxytryptamine-6 Receptors and as Potential Cognition Enhancers. J. Med. Chem. 2012, 55, 5704-5719. [CrossRef] [PubMed]

48. Kode. Available online: https://chm.kode-solutions.net/products_dragon.php (accessed on 15 October 2020). 